\title{
Stress-Induced Reinstatement of Drug Seeking: 20 Years of Progress
}

\author{
John R Mantsch ${ }^{\star, 1}$, David A Baker ${ }^{1}$, Douglas Funk ${ }^{2}$, Anh D Lê ${ }^{2}$ and Yavin Shaham ${ }^{\star, 3}$ \\ ${ }^{1}$ Department of Biomedical Sciences, Marquette University, Milwaukee, Wisconsin, USA; ${ }^{2}$ Center for Addiction and Mental \\ Health, Campbell Family Mental Health Research Institute, University of Toronto, Toronto, ON, Canada; ${ }^{3}$ Intramural Research \\ Program, NIDA-NIH, Baltimore, MD, USA
}

In human addicts, drug relapse and craving are often provoked by stress. Since 1995, this clinical scenario has been studied using a rat model of stress-induced reinstatement of drug seeking. Here, we first discuss the generality of stress-induced reinstatement to different drugs of abuse, different stressors, and different behavioral procedures. We also discuss neuropharmacological mechanisms, and brain areas and circuits controlling stress-induced reinstatement of drug seeking. We conclude by discussing results from translational human laboratory studies and clinical trials that were inspired by results from rat studies on stress-induced reinstatement. Our main conclusions are (1) The phenomenon of stress-induced reinstatement, first shown with an intermittent footshock stressor in rats trained to self-administer heroin, generalizes to other abused drugs, including cocaine, methamphetamine, nicotine, and alcohol, and is also observed in the conditioned place preference model in rats and mice. This phenomenon, however, is stressor specific and not all stressors induce reinstatement of drug seeking. (2) Neuropharmacological studies indicate the involvement of corticotropin-releasing factor (CRF), noradrenaline, dopamine, glutamate, kappa/dynorphin, and several other peptide and neurotransmitter systems in stress-induced reinstatement. Neuropharmacology and circuitry studies indicate the involvement of CRF and noradrenaline transmission in bed nucleus of stria terminalis and central amygdala, and dopamine, CRF, kappa/dynorphin, and glutamate transmission in other components of the mesocorticolimbic dopamine system (ventral tegmental area, medial prefrontal cortex, orbitofrontal cortex, and nucleus accumbens). (3) Translational human laboratory studies and a recent clinical trial study show the efficacy of alpha-2 adrenoceptor agonists in decreasing stress-induced drug craving and stress-induced initial heroin lapse.

Neuropsychopharmacology Reviews (2016) 41, 335-356; doi: I0.1038/npp.20 I5.I42; published online 24 June 2015

\section{INTRODUCTION}

A central feature of drug addiction is the high rate of relapse during abstinence (Hunt et al, 1971; O'Brien, 2005). Over the years, results from many correlational human studies have suggested that this relapse is often provoked by stress (Box 1) (Khantzian, 1985; Shiffman and Wills, 1985; Kosten et al, 1986). These clinical studies have led to the development of a rat model, which is based on the operant conditioning reinstatement model (Stewart and de Wit, 1987), to study mechanisms of stress-induced relapse to drug seeking (Shaham et al, 2000a). In the reinstatement model, laboratory animals are tested for reinstatement of drug seeking induced by drug priming, discrete cues, discriminative cues,

*Correspondence: Dr J Mantsch, Department of Biomedical Sciences, Marquette University, Milwaukee, WI, USA, Tel: 414288 2036,

E-mail: john.mantsch@marquette.edu or Dr Y Shaham, Intramural Research Program, NIDA-NIH, Baltimore, MD, USA, Tel: 443740 2723, Fax: 443740 2827, E-mail: yshaham@intra.nida.nih.gov

Received 24 March 2015; revised 1 May 2015; accepted 8 May 2015; accepted article preview online 15 May 2015 contextual cues, or stressors, following drug self-administration training (typically lever pressing or nose poking for drug infusions) and subsequent extinction of the drugreinforced responding (Shaham et al, 2003; Stewart and de Wit, 1987). The first study using the reinstatement model was published in 1995 using male and female rats that were trained to self-administer heroin for 12 days for $12 \mathrm{~h} /$ day. In this study, acute exposure to $10 \mathrm{~min}$ of intermittent footshock stress immediately before the test sessions reinstated heroin seeking after 1-2 weeks of extinction training and after an additional 4- to 6-week drug-free period (Shaham and Stewart, 1995) (Figure 1).

In this review, we summarize results from studies published during the last 20 years in which investigators have used different variations of the stress-induced reinstatement model to study behavioral, neuropharmacological, and neuroanatomical mechanisms of stress-induced reinstatement of drug seeking. We also summarize results from human studies that have determined the degree to which the results from the preclinical studies 'translate' to the human condition. The material in our review overlaps to some 
degree with previous reviews (Bossert et al, 2005, 2013; Lu et al, 2003; Mantsch et al, 2014; Shaham et al, 2003; Shalev et al, 2010, 2002; Sinha et al, 2011b), but provides the only comprehensive review uniquely dedicated to the phenomenon of stress-induced reinstatement across drug classes since an early review in 2000 (Shaham et al, 2000a). Since 1995 , over 200 papers have been published on this phenomenon (PubMed, Figure 2). Due to space limitations, we do not cover all published papers on this topic in our review.

\section{GENERALITY OF STRESS-INDUCED REINSTATEMENT}

\section{Generality to Other Drug and Non-Drug Rewards}

Early studies showed that the effect of intermittent footshock on reinstatement of heroin seeking generalized to male rats with a history of cocaine (Erb et al, 1996), alcohol (Le et al, 1998), nicotine (Buczek et al, 1999), and methamphetamine (Shepard et al, 2004) self-administration (Figure 1). In contrast, several early studies showed that exposure to an intermittent footshock stressor that reinstates drug seeking (Shaham et al, 2000a) does not reinstate food reward seeking in male rats trained to self-administer food pellets (Ahmed and Koob, 1997), sucrose pellets (Le et al, 1998; Mantsch and

\section{BOX 1 The Stress Concept}

Stress is a complex psychological construct that despite many decades of research (Cannon, 1935; Selye, 1936) lacks a singular operational definition (Chrousos and Gold, 1992; Cohen et al, 1982). In animal models of psychiatric disorders, stress can be broadly defined as forced exposure to events or conditions that are normally avoided (Piazza and Le Moal, 1998). In humans, the stress definition is often extended to incorporate cognitive and emotional responses as suggested by Cohen et al (1986): 'stress is a condition in which the environmental demands exceed the coping abilities of the individual.' In laboratory animals, the precipitating events or conditions can be divided into two main categories (Lu et al, 2003). The first includes aversive conditions like restraint, footshock, tail pinch, social defeat, or pharmacological stressors like exogenous CRF that the rat would avoid if given the opportunity. The second includes conditions like food deprivation, social isolation, or maternal deprivation; each consists of the removal of an environmental condition that is important for maintaining the animal's normal steady-state conditions, a state that the subject will attempt to ameliorate by seeking food, conspecific partners, or the dam.
Goeders, 1999), or sucrose solution (Buczek et al, 1999). However, more recently, Chen et al (2014b) showed that intermittent footshock modestly reinstates palatable food (high carbohydrate pellets) seeking in female rats with a history of 'cafeteria diet' consumption during adolescence. There is also evidence that intermittent footshock stress reinstates operant responding previously reinforced by brain stimulation reward (Shalev et al, 2000); this finding is in agreement with results from an early study (Deutch and Howarth, 1962). In the studies described above, and in others reviewed below, the intermittent footshock stressor and other stressors (with the exception of 1 day food deprivation) were administered acutely just before the reinstatement test sessions.

The reasons for the 'selective' effect of intermittent footshock stress on reinstatement of drug $v s$ food reward are unknown. As previously discussed, one possibility is that while certain physiological effects of intermittent footshock promote reward seeking, other effects of footshock induce physiological states that inhibit food intake and seeking (Shaham et al, 2000a). In this regard, one potential mechanism is hypothalamic corticotropin releasing factor (CRF), which is released after exposure to footshock and other stressors (Bale and Vale, 2004; Sawchenko et al, 2000),

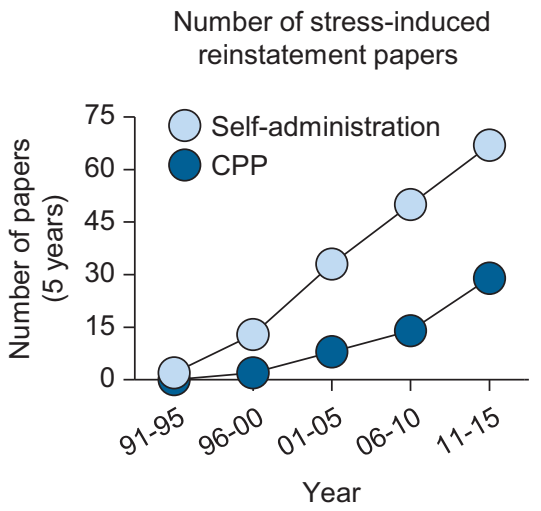

Figure 2. Publications on stress-induced reinstatement. Number of preclinical publications per 5-year period on stress-induced reinstatement of drug self-administration and CPP since 1995.

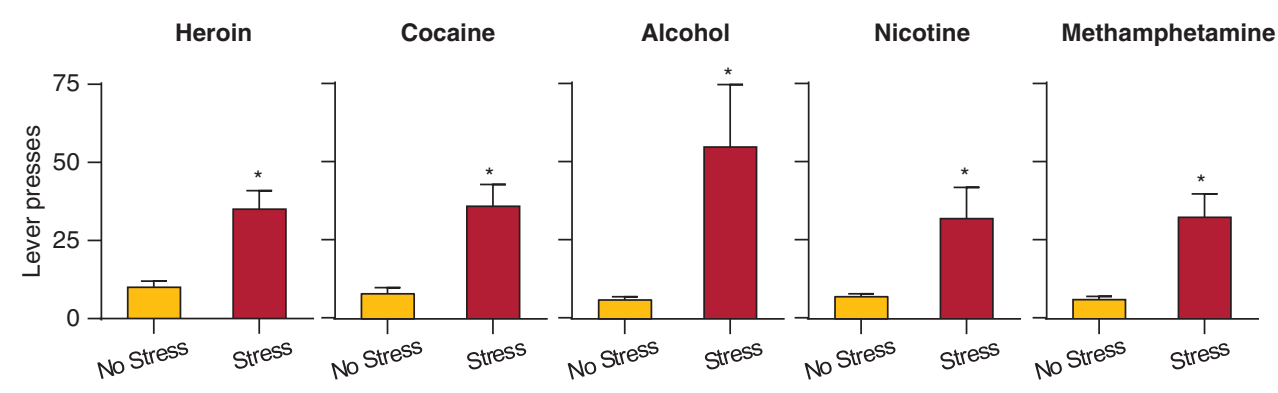

Figure 1. Effect of intermittent footshock stress on reinstatement across drug classes. Data are mean \pm SEM non-reinforced active lever presses after exposure to intermittent footshock or no shock immediately before the reinstatement tests in rats with a history of heroin, cocaine, alcohol, nicotine, or methamphetamine self-administration. The session duration was $3 \mathrm{~h}$ for heroin and cocaine, $1 \mathrm{~h}$ for alcohol and nicotine, and $2 \mathrm{~h}$ for methamphetamine. The intermittent footshock ( $0.5 \mathrm{~s} \mathrm{ON}$; mean inter-shock-interval $40 \mathrm{~s}$ ) duration was $10 \mathrm{~min}$ for heroin and cocaine, 5 min for alcohol and methamphetamine, and 15 min for nicotine. Data were redrawn from Buczek et al (1999), Erb et al (1996), Le et al (1998), Shaham and Stewart (1995), and Shepard et al (2004). *Different from the no stress condition, $p<0.05$. 
and causes inhibition of food intake (Glowa et al, 1992; Morley and Levine, 1982; Sekino et al, 2004). As discussed below (section 'Brain areas and circuits of stress-induced reinstatement'), this classical effect of CRF on the hypothalamic-pituitary adrenal (HPA) axis (Dallman et al, 1995) contrasts with CRF actions on extrahypothalamic systems, which promote stress-induced reinstatement of drug seeking (Erb et al, 2001b). It is also possible that the 'putative' selective effect of intermittent footshock on reinstatement of drug $v s$ food seeking is due to the fact that the above negative studies with food were performed under experimental conditions in which footshock stress-induced reinstatement is often not observed with drugs like cocaine (eg, limited access daily sessions) (see section 'Methodological considerations').

\section{Generality to Other Behavioral Procedures}

In the studies described in section 'Generality to other drug and non-drug rewards', footshock stress-induced reinstatement was determined using the operant version of the extinction-reinstatement model (Shaham et al, 2003). The effect of this stressor was also demonstrated in the conditioned place preference (CPP) variation of the model using cocaine (Wang et al, 2000). In the CPP reinstatement model, laboratory animals are trained to associate a distinct environment with drug injections, undergo extinction training during which they are exposed to the drug environment in the absence of drug, and then tested for reinstatement of drug CPP after stress exposure (Sanchez and Sorg, 2001; Wang et al, 2000). There is also evidence that intermittent footshock can re-establish morphine or cocaine CPP under experimental conditions in which the drug CPP is no longer observed after the passage of time without extinction training (Lu et al, 2000, 2001). Reinstatement of drug seeking after extinction has also been assessed in the runway operant model (Ettenberg, 2009; Ettenberg et al, 1996). To date, however, we are not aware of published studies on the effect of intermittent footshock or other stressors on reinstatement of drug seeking in this model.

\section{Generality to Other Stressors}

Over the years, investigators have determined whether stressors other than intermittent footshock reinstate operant drug seeking or drug CPP. We discuss these results separately for the self-administration and CPP variations of the reinstatement model. Table 1 provides a summary of the text in section 'Generality to other stressors'.

Stress-induced reinstatement of drug self-administration. Acute 1-day food deprivation reinstates heroin and cocaine seeking (Shalev et al, 2000, 2003); these results are in agreement with an earlier finding that food restriction (about $30-40 \%$ of daily food ration) reinstates cocaine seeking in rats with a history of exposure to this stressor during the training phase (Carroll, 1985). Acute 1-day food deprivation
TABLE 1 Effects of Different Stressors on Reinstatement of Operant Drug Seeking and Conditioned Place Preference (CPP)

\begin{tabular}{|c|c|c|c|c|c|c|c|}
\hline & \multicolumn{5}{|c|}{ Self-administration } & \multicolumn{2}{|c|}{$\mathrm{CPP}$} \\
\hline & Heroin & Cocaine & METH & Nicotine & Alcohol & Morphine & Cocaine \\
\hline \multicolumn{8}{|l|}{ Environmental stressors } \\
\hline $\begin{array}{l}\text { Intermittent } \\
\text { Footshock }\end{array}$ & Yes & Yes & Yes & Yes & Yes & Yes & Yes \\
\hline Food deprivation & Yes & Yes & & & & No & \\
\hline Swim stress & & Yes & & & & Yes & Yes \\
\hline $\begin{array}{l}\text { Cue paired with } \\
\text { shock }\end{array}$ & No & No & & & Yes & & Yes \\
\hline Social defeat & & & & & No & Yes & Yes \\
\hline $\begin{array}{l}\text { Cue paired with } \\
\text { social defeat }\end{array}$ & & & & & Yes & & \\
\hline Restraint & No & & & & & Yes & Yes \\
\hline Tail pinch & & & & & & Yes & \\
\hline Quinine solution & & Yes & & & & & \\
\hline \multicolumn{8}{|c|}{ Pharmacological and neuropharmacological stressors } \\
\hline CRF & Yes & Yes & & & & & \\
\hline Yohimbine & Yes & Yes & Yes & Yes & Yes & & Yes \\
\hline Kappa agonists & & Yes & & & & & Yes \\
\hline GABAA antagonists & No & No & & & No & & \\
\hline Metyrapone & Yes & & & & & & \\
\hline $\begin{array}{l}\text { Medial septum } \\
\text { inactivation }\end{array}$ & Yes & & & & & & \\
\hline
\end{tabular}

Abbreviations: CRF, corticotropin-releasing factor; $\mathrm{METH}$, methamphetamine.

also reliably reinstates cocaine seeking in mice (Highfield et al, 2002). Exposure to cues previously paired with social defeat stress, but not acute exposure to social defeat, modestly reinstates alcohol seeking (Funk et al, 2005). Conrad et al (2010) showed that acute exposure (4-5 min) to cold swim stress $24 \mathrm{~h}$ before the reinstatement tests reinstates cocaine seeking. Most recently, Twining et al (2015) showed that acute intraoral delivery of an aversive bitter quinine solution reinstates cocaine seeking.

Pharmacological induction of a stress-like state by ventricular CRF injections reinstates heroin (Shaham et al, 1997), alcohol (Le et al, 2002), and cocaine (Erb et al, 2006) seeking. Similarly, systemic injections of the alpha-2 adrenoceptor antagonist yohimbine, which induces stress- and anxiety-like responses in humans and laboratory animals (Bremner et al, 1996a and b), reinstate methamphetamine (Shepard et al, 2004), alcohol (Le et al, 2005), cocaine (Feltenstein and See, 2006), and nicotine (Feltenstein et al, 2012) seeking in rats, and cocaine seeking in monkeys (Lee et al, 2004). However, the relevance of the potent effect of yohimbine on reinstatement of drug seeking to the general phenomenon of stress-induced reinstatement has been questioned in a recent study (Chen et al, 2014c) (see Box 2).

Another class of putative pharmacological stressors is kappa opioid receptor (KOR) agonists, which induce stresslike states in humans and laboratory animals (Bruchas et al, 2010; Van't Veer and Carlezon, 2013). In rats, systemic injections of the KOR agonist U50,488 reinstate nicotine and 
Yohimbine is an alpha-2 adrenoceptor antagonist that has been used in numerous psychiatry-related studies as a pharmacological stressor in rodents, monkeys, and humans (Bremner et al, 1996a and b; Redmond and Huang, 1979). Over the last decade, yohimbine has become the most common stress manipulation in studies on reinstatement of drug and food seeking (Bossert et al, 2013; Calu et al, 2014; Nair et al, 2009) for three main reasons. The first is that the effect of yohimbine on reinstatement is less variable and more robust than the effect of intermittent footshock (Le et al, 2005; Shepard et al, 2004). The second is that early studies showed that like intermittent footshock the effect of yohimbine on reinstatement of food and alcohol is blocked by CRFI receptor antagonists, which likely act at extrahypothalamic brain areas (Ghitza et al, 2006; Marinelli et al, 2007). The third reason was the intuitive appeal of using the same stressor in the animal model and in humans (Greenwald et al, 20I3; See and Waters, 20I0). However, with the increasing use of yohimbine in reinstatement studies, evidence emerges for behavioral and pharmacological differences between the effects of intermittent footshock and yohimbine on reward seeking. Unlike footshock, yohimbine reinstates food seeking and also increases alcohol and food self-administration (Cifani et al, 20 I2; Le et al, 2005). Unlike intermittent footshock, yohimbine does not induce stress-related $22 \mathrm{kHz}$ ultrasonic distress vocalizations (Mahler et al, 20l3). Unlike intermittent footshock, the effect of yohimbine on reinstatement of cocaine seeking or cocaine CPP is not blocked by the alpha-2 adrenoceptor agonist clonidine (Brown et al, 2009; Mantsch et al, 20 I0). These differences between yohimbine and intermittent footshock raise the possibility that the effect of yohimbine on reinstatement of reward seeking might not be due to its ability to induce a stress-like state that motivates drug or food seeking.

This issue was addressed in a recent study by Chen et al $(2014 \mathrm{c})$ in which they determined whether yohimbine's effect on operant responding is dependent on previous reward history or cue contingency, and whether yohimbine (at a dose used in reinstatement studies) induces an aversive stress-like state, as assessed by the CPP/CPA (conditioned place aversion) method. Chen et al reported that the magnitude of yohimbine-induced operant responding during the reinstatement tests was critically dependent on the contingency between lever pressing and discrete tone-light cue delivery, but not the previous history with food reward during training. Specifically, yohimbine potently and dose-dependently increased operant lever-pressing that was not previously reinforced with either food or drug. They also showed that repeated pairing of yohimbine ( $2 \mathrm{mg} / \mathrm{kg}$ ) with a distinct context causes modest CPP to this context. The highly unexpected conclusion from this study was that yohimbine's effects on operant responding in reinstatement studies are likely independent of the history of contingent self-administration of food or drug rewards and may not be related to the commonly assumed stresslike effects of yohimbine. Chen et al $(2014 \mathrm{c})$ proposed that the primary action of yohimbine in reinstatement studies is to invigorate responding for cues, which before pairing with drug or non-drug rewards or after extinction, have weak motivational effects in rodents.

alcohol seeking (Funk et al, 2014; Grella et al, 2014). In monkeys, systemic injections of KOR agonists (spiradoline and enadoline) reinstate cocaine seeking (Valdez et al, 2007). Another potential demonstration of the effect of pharmacological stressors on reinstatement is the finding that metyrapone potently reinstates heroin seeking (Shaham et al, 1997). Metyrapone is a corticosterone synthesis inhibitor (Jenkins et al, 1958) that has been used in numerous endocrinology studies (Haynes, 1990). However, the drug also activates extrahypothalamic brain areas, including the central amygdala (CeA) nucleus (Rotllant et al, 2002), which has an important role in stress-induced reinstatement (section 'Brain areas and circuits of stress-induced reinstatement'). Finally, another class of pharmacological stressors, GABAa antagonists or inverse receptor agonists like pentylenetetrazole or FG7142, had no effect on reinstatement of cocaine (Waters and See, 2011), heroin, or alcohol (Y Shaham, AD Le, unpublished observations) seeking.

One study showed that a cue previously paired with footshock (a conditioned fear manipulation) reinstates alcohol seeking (Liu and Weiss, 2003). However, earlier studies reported that conditioned fear exposure has no effect on reinstatement of heroin or cocaine seeking (Shaham et al, 2000a). A possible reason for the negative results is that the predominant effect of cues paired with shock is freezing (LeDoux, 2000), a behavior that is incompatible with leverpressing behavior. Exposure to restraint stress in a novel context had no effect on reinstatement of heroin seeking (Shalev et al, 2000). As intermittent footshock stress is effective when given in the drug self-administration context, but has no effect on reinstatement of heroin seeking when given in a novel context, a potential account for the negative results with restraint stress is that the phenomenon of stressinduced reinstatement is context-specific (Shalev et al, 2000). Finally, the effect of footshock on reinstatement of heroin seeking is mimicked by reversible inactivation of the medial septum (Highfield et al, 2000). Previous studies have shown that septal lesions cause stress-like physiological and psychological responses (Gray, 1987; Holdstock, 1967).

Stress-induced reinstatement of CPP. Exposure to several stressors induces reinstatement of drug CPP after extinction in rats and mice. Swim stress reinstates cocaine CPP in mice (Carey et al, 2007; Kreibich and Blendy, 2004; Redila and Chavkin, 2008) and morphine CPP in rats (Li et al, 2013; Ma et al, 2007). Restraint stress reinstates cocaine CPP in rats (Sanchez et al, 2003) and morphine CPP in mice (Ribeiro Do Couto et al, 2006). Tail pinch and social defeat reinstate morphine CPP in mice (Ribeiro Do Couto et al, 2006). A conditioned fear manipulation reinstates cocaine CPP in rats (Sanchez and Sorg, 2001). Additionally, as in the operant reinstatement model, systemic injections of the putative pharmacological stressors U50,488 (a KOR agonist) (Redila and Chavkin, 2008) and yohimbine (Mantsch et al, 2010) reinstate cocaine CPP in mice. However, 1-day food deprivation, which reinstates operant heroin seeking in rats (Shalev et al, 2000), has no effect on reinstatement of morphine CPP (Ma et al, 2007).

\section{Methodological Considerations}

In the sections above, we summarize results from studies in which stressors reinstate drug seeking and CPP. However, particularly in the case of the intermittent footshock stressor, whether or not the stressor reinstates operant drug seeking is dependent on several critical methodological factors. One factor is the context of footshock exposure: under identical experimental conditions, intermittent footshock reinstates heroin seeking when it is administered in the drug selfadministration context but not in a novel context (Shalev et al, 2000). These findings are in agreement with results from conditioned fear studies where a footshock previously paired with a conditioned stimulus (CS) reinstates the 
response to the CS after extinction only when rats are exposed to the stressor in the training context, but not in a novel context (Bouton and King, 1983; Bouton and Swartzentruber, 1991).

A second factor is the duration of the withdrawal period. Shalev et al (2001) used a variation of the reinstatement model in which extinction of operant responding and subsequent footshock-induced reinstatement is determined in the same daily session (Shalev et al, 2002) to demonstrate the time-dependent changes in this reinstatement after withdrawal from heroin. The stressor reinstated heroin seeking after $6,12,25$, and 66 withdrawal days but not after 1 day. In this study, the magnitude of stress-induced reinstatement was maximal after 6 or 12 days.

A third factor is the amount of drug intake during drug self-administration training. For both heroin (Ahmed et al, 2000) and cocaine (Mantsch et al, 2008), intermittent footshock-induced reinstatement of drug seeking is higher in magnitude and more robust/reliable in rats with a history of extended daily drug access (6-11 h/day) than in rats with a history of limited daily drug access (1-2 h/day).

A fourth factor is the availability of discrete infusion cues during all phases of the experiment (training, extinction, and reinstatement). Shelton and Beardsley (2005) showed that under identical experimental conditions, intermittent footshock reinstates cocaine seeking in the presence but not in the absence of a discrete infusion cue previously paired with cocaine infusions during training. This finding is in agreement with the notion that a potential mechanism for footshock-induced reinstatement is that the stressor reinstates the incentive motivational effects of drug cues (Shaham and Stewart, 1995). Additional support for this notion is that intermittent footshock potentiates cue-induced reinstatement of cocaine and alcohol seeking (Buffalari and See, 2009; Liu and Weiss, 2002a). In the cue-induced reinstatement procedure, an operant response reinforced by a discrete drug cue is determined after drug selfadministration training in the presence of the cue and extinction training in its absence (Meil and See, 1996).

A fifth factor is baseline stress levels before footshock exposure during the reinstatement tests. In general, while this variable has not been experimentally manipulated like the other factors described above, anecdotal evidence suggests that footshock-induced reinstatement is not readily observed when the baseline stress level is high, because under these conditions the predominant effect of the stressor during the reinstatement test is prolonged freezing. This idea has led to the development of a modified stress-induced reinstatement procedure in which rats are first given several days of extinction training, and during the subsequent reinstatement test they are given several hours of extinction training before footshock exposure (Erb et al, 1996; Kupferschmidt et al, 2011). Presumably, intermittent footshock reliably reinstates drug seeking in this procedure because the rat's basal stress level is relatively low several hours after being exposed to non-specific stressors (eg, handling and transferred from the animal facility to the test chambers).

\section{Summary}

The phenomenon of intermittent footshock stress-induced reinstatement of drug seeking, originally reported with heroin-trained rats, generalizes to other drugs of abuse and is also observed in the CPP variation of the reinstatement model. This phenomenon also generalizes to certain environmental and pharmacological stressors but not others. Additionally, it appears that the number of stressors that are effective in the CPP variation of the reinstatement model is more diverse than in the operant variation of the model (Table 1). Furthermore, several methodological factors are critical for a reliable effect of intermittent footshock stress on reinstatement of drug seeking. These factors include the context of footshock exposure, high drug intake during training, the withdrawal period duration, the presence of the extinguished discrete drug cues during testing, and basal (baseline) stress levels before footshock exposure in the reinstatement tests.

Finally, in all the published studies on stress-induced reinstatement, the reinstating stressors have been both uncontrollable and unpredictable. Thus, a question for future research is whether these features of stressors are critical for their effect on reinstatement of drug seeking. Based on previous studies investigating the inhibitory effect of both stress controllability and predictability on physiological and psychological stress responses in laboratory animals (Maier, 1984; Seligman and Maier, 1967) and humans (Cohen et al, 1986; Glass and Singer, 1972), we predict that controllable or predictable stressors will have a weak effect on reinstatement of drug seeking. Additionally, in the studies reviewed above, the stressors were administered acutely before the reinstatement test session. Thus, another question for future research is whether prior exposure to stress, which often leads to subsequent sensitization of stress responses (Antelman et al, 2000; Kvetnansky et al, 2009) and cross sensitization of the behavioral and neurochemical responses to drugs (Kalivas and Stewart, 1991), would potentiate the stressors' effect on reinstatement of drug seeking.

\section{BRAIN AREAS AND CIRCUITS OF STRESS-INDUCED REINSTATEMENT}

Since 1995 many studies have determined the effects of systemic and intracranial injections of pharmacological agents targeting different receptor classes on stress-induced reinstatement of drug seeking or CPP. Due to space limitations, we summarize most of the systemic pharmacology data in Tables 2 and 3 but do not discuss them in detail in our review. The brain circuitry data that we discuss below are primarily based on the use of intermittent footshock in the self-administration- and CPP-based reinstatement models with different drug classes in rats, and the use of swim stress in the CPP-based procedure with cocaine in mice. 
TABLE 2 Effect of Systemic Injections of Different Pharmacological Agents on Stress-Induced Reinstatement of Operant Drug and Food Seeking

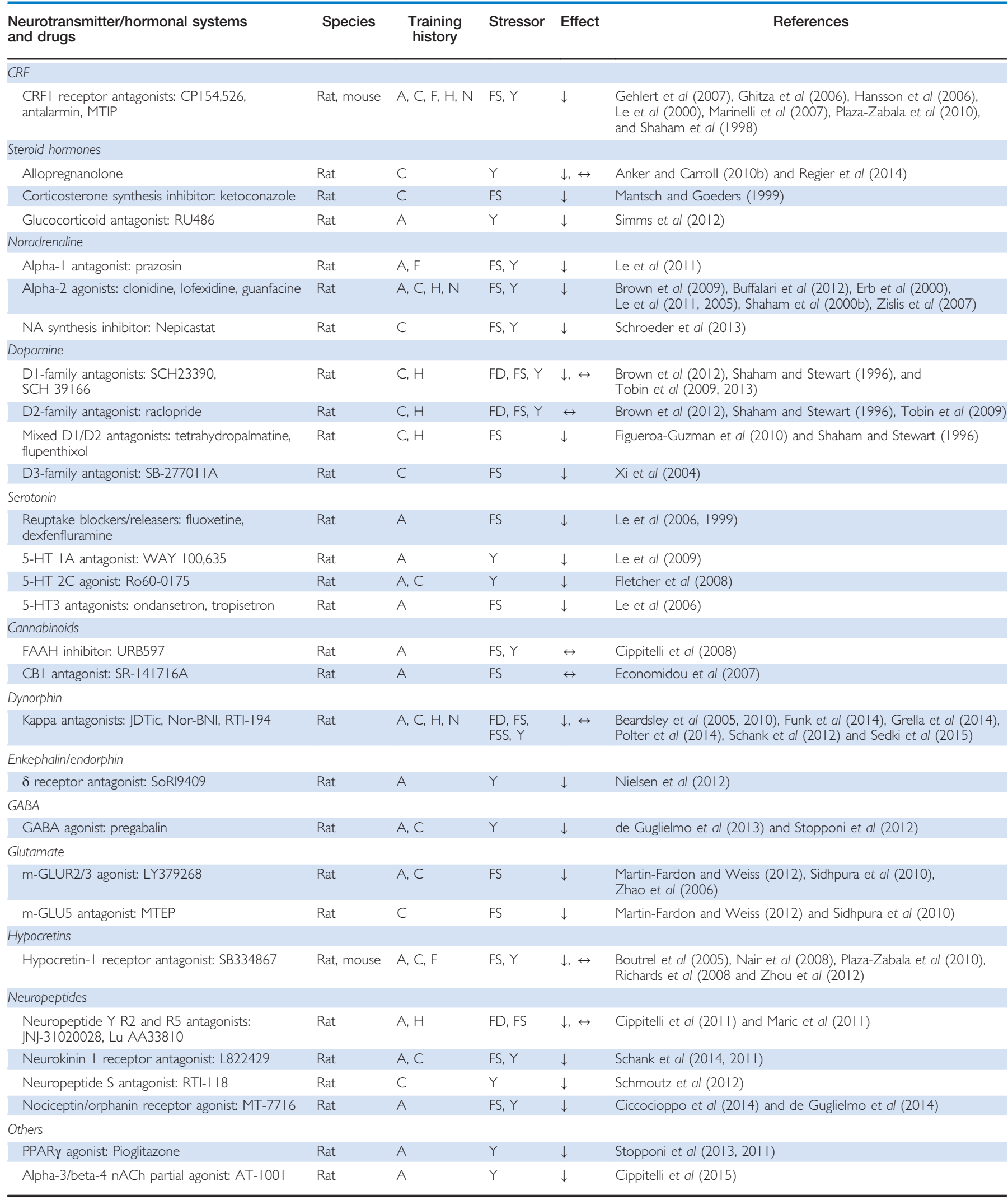

Abbreviations for training history: A, alcohol; $\mathrm{C}$, cocaine, F, food; H, heroin; $\mathrm{M}$, methamphetamine; $\mathrm{N}$, nicotine. Abbreviations for stressors: FD, food deprivation ( $\mathrm{d}$ ); FS, intermittent footshock; FSS, forced swim stress; Y, yohimbine. Abbreviations for symbols: $\downarrow$, decrease; $\leftrightarrow$, no effect. 
TABLE 3 Effect of Systemic Injections of Different Pharmacological Agents on Stress-Induced Reinstatement of Conditioned Place Preference

\begin{tabular}{|c|c|c|c|c|c|}
\hline $\begin{array}{l}\text { Neurotransmitter/hormonal systems } \\
\text { and drugs }\end{array}$ & Species & $\begin{array}{l}\text { Training } \\
\text { history }\end{array}$ & Stressor & Effect & References \\
\hline \multicolumn{6}{|l|}{ CRF } \\
\hline \multicolumn{6}{|l|}{ Noradrenaline } \\
\hline Alpha-I antagonist: Prazosin & Mouse & C & FSS, Y & $\leftrightarrow$ & Mantsch et al (20।0) \\
\hline Alpha-2 agonist: Clonidine & Mouse & C & FSS, Y & $\downarrow, \leftrightarrow$ & Mantsch et al (20|0) \\
\hline Beta-2 antagonists: Propranolol, ICl- | | 8,55 | & Mouse & C & FSS, Y & $\downarrow$ & Mantsch et al (20|0) and Vranjkovic et al (20|2) \\
\hline \multicolumn{6}{|l|}{ Cannabinoids } \\
\hline Cannabinoid antagonist: AM-25I & Rat & C & FSS & $\downarrow$ & Vaughn et al (20|2) \\
\hline \multicolumn{6}{|l|}{ Dynorphin } \\
\hline $\begin{array}{l}\text { Kappa antagonists: Nor-BNI, CJ-15,208, } \\
\text { PF-04455242, Zyklophin }\end{array}$ & Mouse & C, N & FSS & $\downarrow$ & $\begin{array}{l}\text { Aldrich et al (2009, 20।3), Eans et al (2013), Grimwood et al (201 I), } \\
\text { Jackson et al (2013), McLaughlin et al (2003) and Redila and Chavkin (2008) }\end{array}$ \\
\hline \multicolumn{6}{|l|}{ Other transmitters } \\
\hline NMDA 2B receptor antagonist: ifenprodil & rat & M & FSS & $\leftrightarrow$ & Ma et al (2007) \\
\hline
\end{tabular}

Abbreviations for training history: $A$, alcohol; $C$, cocaine, $M$, morphine; N, nicotine. Abbreviations for stressors: FS, intermittent footshock; FSS, forced swim stress; Y, yohimbine. Abbreviations for symbols: $\downarrow$, decrease; $\leftrightarrow$, no effect.

During the last several years, many investigators have also determined the neuropharmacological mechanisms underlying yohimbine-induced reinstatement of drug seeking and CPP (Bossert et al, 2013; Mantsch et al, 2014; See and Waters, 2010). However, as discussed in Box 2, yohimbine's effects on operant responding during reinstatement testing are likely independent of the history of contingent drug self-administration and may not be related to the commonly assumed stress-like effects of yohimbine. Therefore, we only mention results from yohimbine-related studies when a given neuropharmacological manipulation affected both intermittent footshock- and yohimbineinduced reinstatement.

\section{Bed Nucleus of Stria Terminalis and CeA}

The bed nucleus of stria terminalis (BNST) and the CeA are known to have important roles in stress responses (Davis et al, 2010; LeDoux, 2000) that involve activation of noradrenaline and CRF systems (Davis et al, 1997; Flavin and Winder, 2013; McGaugh, 2004; Silberman and Winder, 2013). Studies using systemic or ventricular drug injections have shown that CRF receptor antagonists and alpha-2 adrenoceptor agonists like clonidine (which inhibit noradrenaline cell firing and release) decrease stress-induced reinstatement of drug seeking and drug CPP (Mantsch et al, 2014; Shaham et al, 2000a; Shalev et al, 2010) (Tables 2 and 3). Conversely, ventricular injections of CRF or noradrenaline mimic the effect of intermittent footshock stress on reinstatement (Brown et al, 2009; Erb et al, 2006; Le et al, 2000; Shaham et al, 1997). Studies using endocrinology methods (adrenalectomy, corticosterone replacement) have also shown that CRF's role in footshock-induced reinstatement does not involve stress-induced activation of the HPA axis, indicating a role of extrahypothalamic CRF systems (Erb et al, 2001a; Lu et al, 2003). Based on these results, investigators have studied the involvement of CRF and noradrenaline in BNST and CeA in stress-induced reinstatement and CPP. We describe these studies below. (Note: in Box 3 we discuss in more detail the role of corticosterone and the HPA axis in stress-induced reinstatement.)

The CRF projections from CeA to BNST. Erb and Stewart (1999) showed that injections of the CRF receptor antagonist D-Phe $\mathrm{CRF}_{12-41}$ into the BNST (ventral region) but not CeA decrease footshock-induced reinstatement of cocaine seeking. They also showed that CRF injections into the BNST but not CeA reinstate cocaine seeking; this finding was confirmed by Vranjkovic et al (2014). In agreement with these findings, Wang et al (2006) showed that BNST but not $\mathrm{CeA}$ injections of the selective CRF1 receptor antagonist CP-154,526 (Schulz et al, 1996) decrease footshock-induced reinstatement of morphine CPP. However, while blockade or activation of CeA CRF receptors had no effect on footshockinduced reinstatement, Erb et al (2001a) reported data suggesting that a CRF projection from CeA to BNST (Sakanaka et al, 1986) has a role in this reinstatement. They used an asymmetric anatomical disconnection method (Gold, 1966) and showed that injections of tetrototoxin (TTX, a sodium channel blocker that inhibits neuronal activity) into the CeA in one hemisphere and D-Phe $\mathrm{CRF}_{12-41}$ into the BNST in the contralateral hemisphere decrease footshock-induced reinstatement of cocaine seeking. 
BOX 3 Corticosterone, the HPA Axis, and Stress-Induced Reinstatement

As mentioned in the main text, studies using endocrinology methods of adrenalectomy and adrenalectomy plus corticosterone replacement showed that stress-induced activation of the HPA axis and subsequent release of corticosterone does not have a role in stress-induced reinstatement of drug seeking (Erb et al, 1998; Le et al, 2000; Shaham et al, 1997; Shalev et al, 2006, 2003; Graf et al, 201 I). However, at least in the case of cocaine, basal corticosterone levels are critical for stress-induced reinstatement (Erb et al, 1998; Shalev et al, 2003), suggesting a permissive role of the stress hormone in this reinstatement. Additionally, exogenous administration of corticosterone reinstates cocaine seeking (Deroche et al, 1997).

More recently, there is evidence for a role of corticosterone in two emerging important phenomena related to stress-induced reinstatement. The first is that as mentioned in section 'Generality of stress-induced reinstatement', footshock stress-induced reinstatement is significantly stronger and more robust in rats with a history of extended ( $6 \mathrm{~h} /$ day $)$ vs limited $(\mathrm{I}-2 \mathrm{~h} /$ day $)$ access to cocaine (Mantsch et al, 20l4). Under these conditions, adrenalectomy before self-administration training prevents stress-induced reinstatement while the same manipulation after training is ineffective (Graf et al, 20l I), suggesting that cocaine-induced corticosterone-dependent neuroadaptations are critical for footshock-induced reinstatement.

Second, there is evidence that footshock, under conditions in which it has no effect on reinstatement on its own, strongly potentiates the ability of both cocaine priming and cocaine cues to reinstate drug seeking (Buffalari and See, 2009; Graf et al, 20/3). The mechanism/s underlying the 'indirect' potentiation effect of stress is largely unknown but it appears that corticosterone has a critical role. Graf et al (2013) showed that this effect of mild stress is reversed by adrenalectomy but not by systemic injections of the glucocorticoid receptor antagonist RU486. Next, these authors showed that the potentiating effect of mild stress on cocaine priming is mediated by a novel mechanism of action in NAc that involves glucocorticoid dependent blockade of dopamine clearance by the monoamine transporter, organic cation transporter 3 (OCT3).

Taken together, these results suggest that stress-induced activation of CRF projections from CeA to BNST and subsequent activation of CRF receptors (presumably the CRF1 subtype) in the BNST are critical for stress-induced reinstatement of drug seeking and CPP. However, the circuitry (projection) data are based on the use of TTX, which also inhibits fiber of passage and non-CRF neurons that project to BNST (Cassell et al, 1999). Therefore, it is likely that within the BNST, CRF-related mechanisms that are independent of the CeA to BNST CRF projection also have a role in stress-induced reinstatement.

Noradrenaline in CeA and BNST and interaction between noradrenaline and CRF in BNST. Leri et al (2002) showed that injections of a mixture of beta- 1 and beta- 2 adrenoceptor antagonists (betaxolol+ICI-118,551) into both the BNST (the injections were in both dorsal and ventral BNST) and the CeA decrease footshock-induced reinstatement of cocaine seeking. Subsequently, Vranjkovic et al (2014) showed that within the ventral BNST, this effect is mediated by the beta- 2 adrenoceptor: local ICI-118,551 but not betaxolol injections decrease stress-induced reinstatement. Additionally, they showed that ventral BNST injections of the beta-2 adrenoceptor agonist clenbuterol, but not the beta1 adrenoceptor agonist dobutamine, mimic the effect of footshock on reinstatement. Additional evidence for a role of BNST and CeA noradrenaline in stress-induced reinstatement is that BNST and CeA injections of clonidine decrease footshock-induced reinstatement of morphine CPP (Wang et al, 2001) and footshock-induced reinstatement of nicotine seeking (Yamada and Bruijnzeel, 2011). These data, however, are difficult to interpret in the absence of additional anatomical and pharmacological controls, because clonidine is highly lipophilic and it can readily diffuse to the nearby areas, or in the case of the BNST, to the ventricles. Finally, based on the earlier results of Leri et al (2002), an unexpected finding of Yamada and Bruijnzeel (2011) is that CeA injections of the non-selective beta adrenoceptor antagonist propranolol have no effect on footshock-induced reinstatement of nicotine seeking.

Ascending noradrenaline systems originate from two clusters of neurons, the locus coeruleus (LC, A6) and the lateral tegmental nuclei (A1, A2 (located in nucleus tractus solitarii, NTS), A4); these neurons project to many brain areas via the dorsal and ventral noradrenergic bundles, respectively (Kvetnansky et al, 2009; Moore and Bloom, 1979). The lateral tegmental nuclei, which provide the main source of noradrenaline to BNST and CeA (Aston-Jones et al, 1999; Fritschy and Grzanna, 1991), but not the LC, are critical for stress-induced reinstatement of drug seeking and CPP. 6-OHDA lesions of the ventral noradrenergic bundle decrease footshock-induced reinstatement of heroin seeking (Shaham et al, 2000b) and morphine CPP (Wang et al, 2001). In contrast, injections of clonidine or its charged analog ST-91 into the LC have no effect on this reinstatement (Shaham et al, 2000b; Wang et al, 2001).

Finally, there is evidence that an interaction between CRF and noradrenaline in the BNST is critical for footshockinduced reinstatement of cocaine seeking. In an initial study, Brown et al (2009) showed that reinstatement of cocaine seeking induced by ventricular injections of noradrenaline is decreased by pretreatment with the CRF receptor antagonist $\mathrm{D}-\mathrm{Phe} \mathrm{CRF}_{12-41}$. In contrast, reinstatement induced by ventricular injections of CRF is not blocked by the alpha- 2 adrenoceptor agonist clonidine. These data suggest that the role of CRF in stress-induced reinstatement is downstream from stress-induced activation of noradrenaline systems. The likely brain site for this noradrenaline-CRF interaction is the BNST. Vranjkovic et al (2014) showed that reinstatement of cocaine seeking induced by ventral BNST injections of the beta-2 adrenoceptor agonist clenbuterol is blocked by local injections of the CRF1 receptor antagonist antalarmin (Bornstein et al, 1998).

Taken together, stress-induced activation of lateral tegmental noradrenergic nuclei and subsequent actions of noradrenaline in both the BNST and CeA are critical for stress-induced reinstatement of drug seeking and CPP. Additionally, within the ventral BNST, stress-induced activation of CRF and subsequent stress-induced reinstatement are downstream from stress-induced activation of lateral tegmental noradrenergic nuclei that project to this brain area.

Other evidence for a role of BNST and CeA in stressinduced reinstatement. Several other lines of evidence also indicate critical roles for the BNST and CeA in stressinduced reinstatement of drug seeking and CPP. Reversible inactivation of ventral BNST or CeA with GABAa and GABAb receptor agonists (muscimol+baclofen) decreases 
footshock-induced reinstatement of cocaine seeking (McFarland et al, 2004). Additionally, TTX injections into either the BNST or CeA decrease footshock-induced reinstatement of heroin seeking (Shaham et al, 2000a) and this reinstatement is associated with increased CRF mRNA in both brain areas (Shalev et al, 2001). However, both sets of data should be interpreted with caution. As mentioned above, a methodological issue with TTX inactivation data is that the drug inactivates both cell bodies and fibers of passage. Additionally, the relevance of the CRF mRNA expression data to CRF's role in stress-induced reinstatement is unclear, because within the BNST footshock selectively increases expression in dorsal but not in ventral BNST, while the pharmacological data described above are primarily based on ventral BNST injections.

Other relevant evidence is that systemic injections of the beta- 2 adrenoceptor antagonist ICI-118,551 decrease swim stress-induced reinstatement of cocaine CPP and prevent increases in CRF mRNA in BNST (but not CeA) in mice (McReynolds et al, 2014). However, under somewhat different experimental conditions, exposure to swim stress increases CRF mRNA in CeA in cocaine-experienced mice (Cleck et al, 2008). In agreement with the latter findings, Nawata et al (2012) showed that a CRF receptor antagonist (alpha-helical-CRF ${ }_{9-41}$ ) decreases footshock-induced reinstatement of methamphetamine seeking in rats; additionally, using enzyme-linked immunosorbent assay (ELISA) they showed that CRF protein levels in CeA are increased after 10 but not 5 days of withdrawal from methamphetamine. The relevance of the ELISA data to the pharmacological data with the CRF receptor antagonist is unknown.

Finally, studies using markers of neuronal activity such as Fos and pCREB (a downstream target of Fos activation) showed that swim stress-induced reinstatement of cocaine CPP in mice is associated with increased CREB activity (phosphorylation) in amygdala but not in BNST (Kreibich and Blendy, 2004). In a subsequent study, however, Briand et al (2010) showed that swim stress increases Fos expression in both ventral and dorsal BNST and that reversible inactivation of the BNST with lidocaine decreases swim stress-induced reinstatement of cocaine CPP. Additionally, Buffalari and See (2011) showed that reversible inactivation with muscimol+baclofen of the BNST decreases yohimbineinduced reinstatement of cocaine seeking and yohimbineinduced potentiation of cue-induced cocaine seeking.

Summary. The studies reviewed above indicate that the BNST (primarily the ventral BNST) and CeA have important roles in stress-induced reinstatement of drug seeking across drug classes and are also involved in stress-induced reinstatement of morphine and cocaine CPP. These roles include stress-induced activation of the lateral tegmental nuclei that provide the main noradrenergic innervation to BNST and CeA, and potentially the CRF projection from $\mathrm{CeA}$ to BNST. Within the BNST, stress-induced CRF activation and subsequent stress-induced reinstatement are likely downstream from stress-induced activation of lateral tegmental noradrenaline neurons.

\section{Ventral Tegmental Area, Media Prefrontal Cortex, Orbital Frontal Cortex, and Nucleus Accumbens}

Neuronal activity in the mesocorticolimbic dopamine system, which comprises cell bodies in ventral tegmental area (VTA) that project to medial prefrontal cortex (mPFC), orbital frontal cortex (OFC), nucleus accumbens (NAc), amygdala, BNST, and other brain areas, has an important role in reinstatement of drug seeking induced by discrete cues (See, 2005), discriminative cues (Weiss, 2005), contextual cues (Marchant et al, 2014), and drug priming (Kalivas and McFarland, 2003; Pierce and Kumaresan, 2006; Self, 2004). Early studies have shown that different stressors strongly and preferentially activate the dopaminergic projection from VTA to mPFC (the mesocortical dopamine system) (Bannon and Roth, 1983; Deutch and Roth, 1990; Thierry et al, 1976). Subsequent studies, however, showed that stressors can also activate the dopaminergic projection from VTA to NAc (a component of the mesolimbic dopamine system) (Cabib and Imperato, 1996; Kalivas and Stewart, 1991).

Based on these findings, the first two studies on intermittent footshock-induced reinstatement of drug seeking explored the role of mesolimbic dopamine. In the first study, Shaham and Stewart (1995) showed that footshockinduced reinstatement of heroin seeking is associated with increased dopamine release in NAc. In the second study, they showed that systemic injections of the mixed dopamine receptor antagonist flupenthixol decrease this reinstatement (Shaham and Stewart, 1996). In a subsequent anatomical mapping study, McFarland et al (2004) showed that reversible inactivation with muscimol+baclofen of VTA, dorsal mPFC, NAc core and shell, and ventral pallidum (a downstream output of NAc via the 'indirect' pathway) decreases footshock-induced reinstatement of cocaine seeking. Below, we describe subsequent mechanistic studies on the role of different brain areas of the mesocorticolimbic system in stress-induced reinstatement of drug seeking and CPP.

Glutamate, CRF, and Kappa/dynorphin in VTA. Glutamate input to VTA arrives from several brain regions (Geisler et al, 2007; Omelchenko and Sesack, 2007) and controls the activity of VTA dopamine neurons under basal conditions (Westerink et al, 1996; White et al, 1995) and after stress exposure (Enrico et al, 1998; Takahata and Moghaddam, 1998). Based on these studies, Wise and colleagues studied the role of VTA glutamate in stress-induced reinstatement of cocaine and heroin seeking. They showed that footshockinduced reinstatement of both heroin and cocaine seeking is associated with increased VTA glutamate release and that this reinstatement is decreased by local blockade of ionotropic glutamate receptors with kynurenic acid (Wang et al, 2005, 2012). 
VTA dopamine and glutamate transmission is also controlled by local CRF signaling (Kalivas et al, 1987; Ungless et al, 2003) from unspecified sources and, as discussed above, CRF has a critical role in stress-induced reinstatement of drug seeking and CPP. Based on these findings, Wise and colleagues studied the role of VTA CRF in stress-induced reinstatement of cocaine seeking. In the first study, they showed that VTA perfusion (via a microdialysis probe) of alpha-helical $\mathrm{CRF}_{9-41}$ decreases footshock-induced reinstatement and that local CRF perfusion reinstates cocaine seeking (Wang et al, 2005); see also Wang et al (2009) for a replication of the VTA CRF effect on reinstatement. Next, they showed that footshock-induced reinstatement of cocaine seeking is decreased by VTA perfusion of a selective CRF2 receptor antagonist or an inhibitor of the CRF binding protein but not by a selective CRF1 receptor antagonist. Moreover, they showed that VTA perfusion of CRF or CRF2 receptor agonists with strong affinity for CRF-BP (binding protein) causes reinstatement of cocaine seeking, whereas CRF receptor agonists that do not bind CRF-BP are ineffective (Wang et al, 2007).

These are surprising findings from two perspectives. The first is that previous studies discussed above (see also Tables 2 and 3) implicate CRF1 but not CRF2 receptors in stressinduced reinstatement. The second is that anatomical studies indicate that CRF1 receptors are the predominant postsynaptic CRF receptors in VTA and that CRF2 receptor expression is not detected by traditional in situ hybridization methods (Van Pett et al, 2000). Another issue to consider in studies using putative selective CRF2 antagonists is that their CRF2/CRF1 ratio selectivity is moderate, and some commonly used CRF2 antagonists like antisauvagine-30 have behavioral effects in CRF2 knockout mice, indicating actions on other receptors (Zorrilla et al, 2013b).

More recent studies demonstrated a role of CRF1 receptors in stress-induced reinstatement of cocaine seeking. Blacktop et al (2011) showed that VTA injections of the CRF1 receptor antagonists antalarmin or CP-376395 but not the CRF2 receptor antagonists astressin-2B or antisauvagine- 30 decrease footshock-induced reinstatement of cocaine seeking in rats. Additionally, VTA injections of the CRF1 receptor agonist cortagine but not the CRF2 receptor agonist rat urocortin II mimic the effect of footshock stress on reinstatement. Chen et al (2014a) showed that local viral-mediated knockdown of VTA CRF1 receptors decreases food deprivation stress-induced reinstatement of cocaine seeking in mice. Vranjkovic et al (2014) also showed that injections of the beta-2 adrenoceptor antagonist ICI-188,551 into the BNST in one hemisphere and the CRF1 receptor antagonist antalarmin into the VTA of the contralateral hemisphere decrease footshock-induced reinstatement of cocaine seeking. These data suggest a potential role of the CRF projection from BNST to VTA (Rodaros et al, 2007), which is activated by noradrenergic projections to BNST (Aston-Jones et al, 1999), in stress-induced reinstatement of cocaine seeking. In this regard, the BNST projection to VTA is also activated during swim stress-induced reinstatement of cocaine CPP in mice, as assessed by double labeling of the activity marker Fos with the retrograde tracer fluorogold gold (injected in VTA) in ventral BNST (Briand et al, 2010).

Two recent studies by Kauer, Pierce and colleagues demonstrate a role of kappa/dynorphin signaling in VTA in cold swim stress-induced reinstatement of cocaine seeking in rats (Graziane et al, 2013; Polter et al, 2014). In this stress reinstatement procedure, short (4-5 $\mathrm{min})$ exposure to cold swim reinstates cocaine seeking $24 \mathrm{~h}$ later (Conrad et al, 2010). These studies were inspired by earlier studies on the regulation of VTA dopamine transmission by local kappa/ dynorphin signaling (Ford et al, 2007; Margolis et al, 2003) and the findings that systemic injections of KOR antagonists decrease stress-induced drug seeking in rats and stressinduced reinstatement of drug CPP in mice (Tables 2 and 3) (Beardsley et al, 2005; Redila and Chavkin, 2008). In the first study, Graziane et al (2013) showed that systemic injections of the KOR antagonist Nor-BNI rescue swim stress-induced abolishment of long-term potentiation (LTP) at GABAergic synapses on VTA dopaminergic neurons. Next, they showed that VTA injections of Nor-BNI decrease stress-induced reinstatement of cocaine seeking. In the second study, Polter et al (2014) showed that acute exposure to swim stress blocks normal LTP at GABAergic synapses on VTA dopaminergic neurons for up to 5 days, an effect dependent on KOR, and that surprisingly, systemic injections of Nor-BNI several hours after swim stress exposure also decrease the stressor's effect on reinstatement $24 \mathrm{~h}$ later.

Summary. The studies reviewed above indicate that footshock stress-induced activation of CRF and glutamate transmission in VTA is critical for the stressor's effect on reinstatement of drug seeking. A recent study by Vranjkovic et al (2014) further suggests that glutamatergic (Georges and Aston-Jones, 2002) and/or CRF (Rodaros et al, 2007) projections from BNST to VTA are the source of this activation. There is also evidence that KOR-mediated stressinduced alterations in GABAergic transmission in VTA have a critical role in the effect of cold swim stress on reinstatement of cocaine seeking.

Dopamine and glutamate in NAc, $m P F C$, and OFC. Studies using intracranial injections of different dopamine receptor antagonists have demonstrated an important role of dopamine transmission in dorsal mPFC (prelimbic area) and OFC in stress-induced reinstatement of cocaine seeking. Capriles et al (2003) showed that dorsal (but not ventral or infralimbic area) $\mathrm{mPFC}$ and OFC injections of the D1-family receptor antagonist $\mathrm{SCH} 23390$ but not the D2-family receptor antagonist raclopride decrease footshock-induced reinstatement of cocaine seeking. McFarland et al (2004) showed that dorsal mPFC injections of the mixed dopamine receptor antagonist flupenthixol decrease this reinstatement. Sanchez et al (2003) showed that SCH23390 injections into dorsal $\mathrm{mPFC}$ decrease restraint stress-induced reinstatement of cocaine CPP. Dorsal mPFC dopamine and neuronal activity in this brain area also have a role in yohimbine- 
induced reinstatement of palatable food seeking in male and female rats (Calu et al, 2013; Cifani et al, 2012; Nair et al, 2011) and acute food deprivation-induced reinstatement of heroin seeking (Tobin et al, 2013). As VTA dopamine neurons project to $\mathrm{MPFC}$ and OFC (Moore and Bloom, 1979), the results from the studies reviewed above indicate that stress-induced activation of the dopaminergic projections from VTA to mPFC (Thierry et al, 1976) and OFC is critical for stress-induced reinstatement. This activation involves D1-family receptors which, in the $\mathrm{mPFC}$, are expressed on pyramidal cells where they promote excitability primarily by increasing NMDA receptor-mediated effects (Lewis and O'Donnell, 2000; Seamans et al, 2001).

McFarland et al (2004) provided additional evidence that the circuit controlling footshock-induced reinstatement of cocaine seeking includes the dopaminergic projection from VTA to dorsal mPFC (prelimbic area), and also provided evidence that the glutamatergic projection from dorsal mPFC to NAc core (Sesack et al, 1989) and potentially the GABAergic projection from NAc shell to VTA (Zahm et al, 2001) (the 'direct' striatal pathway) have a role in this reinstatement. They showed that (1) reversible inactivation of dorsal mPFC decreases both footshock-induced reinstatement and glutamate release in NAc core, (2) reversible inactivation of NAc shell and core, and as mentioned above the VTA, decreases this reinstatement, and (3) that reversible inactivation of NAc shell also decreases stress-induced dopamine release in dorsal mPFC. These authors also showed that reversible inactivation of the ventral pallidum, a main output region of the striatal indirect pathway (Gerfen, 1992), decreases footshock-induced reinstatement. This circuit scheme, however, is speculative in the absence of more direct evidence from studies using classical anatomical asymmetrical disconnection procedures (Setlow et al, 2002) or more recent projection-specific inhibition using optogenetic (Stefanik et al, 2013) or chemogenetic (Mahler et al, 2014) methods.

Evidence for a role of NAc dopamine in stress-induced reinstatement is somewhat mixed. Shaham and Stewart (1995) showed that footshock-induced reinstatement of heroin seeking is associated with increased dopamine levels in NAc. In contrast, McFarland et al (2004) showed that footshockinduced reinstatement of cocaine seeking is not associated with increased dopamine release in NAc and that flupenthixol injections into NAc core have no effect on this reinstatement. However, Xi et al (2004) showed that injections of the preferential D3 receptor antagonist SB-277011A into NAc (injections targeted primarily NAc shell) decrease footshock-induced reinstatement of cocaine seeking. Additionally, Tobin et al (2013) showed that SCH23390 injections into NAc shell but not core decrease food deprivation-induced reinstatement of heroin seeking. Thus, one possible account of these potentially discrepant results is that NAc shell but not core dopamine is critical for stress-induced reinstatement of drug seeking.

Finally, a very recent study by Wheeler and colleagues suggests that at least for one stressor, a bitter quinine solution, reinstatement of cocaine seeking is associated with decreased tonic NAc dopamine levels, as assessed by in vivo voltammetry (Twining et al, 2015). They showed that in cocaine-experienced rats, exposure to quinine reinstates cocaine seeking, and that in drug-naïve rats, the same manipulation decreases tonic dopamine levels in NAc. Both of these effects were reversed by blockade of VTA CRF1 receptors. Together, with the previous results reviewed above, the results from this study suggest that both increases and decreases in NAc dopamine can have a role in stressinduced drug seeking.

Summary. D1 receptor-mediated dopamine transmission in dorsal $\mathrm{mPFC}$ and the glutamatergic projection from this brain area to NAc core are critical for stress-induced reinstatement of cocaine seeking. This reinstatement also likely involves activation of the NAc GABAergic projections to VTA (the direct pathway) and ventral pallidum (the indirect pathway), as well as increased dopamine transmission in NAc shell. A recent study using intraoral delivery of quinine solution as the stressor suggests that stress-induced reinstatement can also be triggered by decreases in NAc dopamine tone.

\section{Median and Dorsal Raphe Nuclei}

Many studies over the last several decades have implicated central serotonin in stress responses (Chaouloff, 1993; Maier, 1984; Maier and Watkins, 2005; Stone, 1983). This literature has led to studies on the role of serotonin in the two main cell body regions of brain serotonergic neuronsmedian raphe nucleus (MRN) and dorsal raphe nucleus (DRN) (Hale and Lowry, 2011; Vertes, 1991; Vertes et al, 1999) - in stress-induced reinstatement of alcohol seeking in rats and stress-induced reinstatement of cocaine and morphine CPP.

Role of MRN in stress-induced reinstatement of alcohol seeking. Le et al (1999) showed that systemic injections of the serotonin reuptake blocker fluoxetine, which increases brain serotonin levels, decrease footshock-induced reinstatement of alcohol seeking, indicating that serotonin negatively regulates this reinstatement. This negative regulation involves the MRN. Local injections of the selective 5-HT1a autoreceptor agonist 8-OH-DPAT, which decrease serotonin cell firing and release (Mongeau et al, 1997), mimic the effect of intermittent footshock on reinstatement (Le et al, 2002). Additionally, these authors showed that MRN injections of the non-selective CRF receptor antagonist $\mathrm{D}-\mathrm{Phe} \mathrm{CRF}_{12-41}$ decrease footshock-induced reinstatement of alcohol seeking while MRN injections of very low doses of CRF (10 ng) partially mimic the stressor's effect on reinstatement. A physiological mechanism that connects the similar effects of 8-OH-DPAT and low-dose CRF injections in MRN on reinstatement is that low CRF doses, like 8-OH-DPAT, decrease serotonin cell firing and release (Kirby et al, 2000; Price et al, 1998). However, to date, this effect has only been reported for DRN but not for MRN neurons. Finally, Le et al 


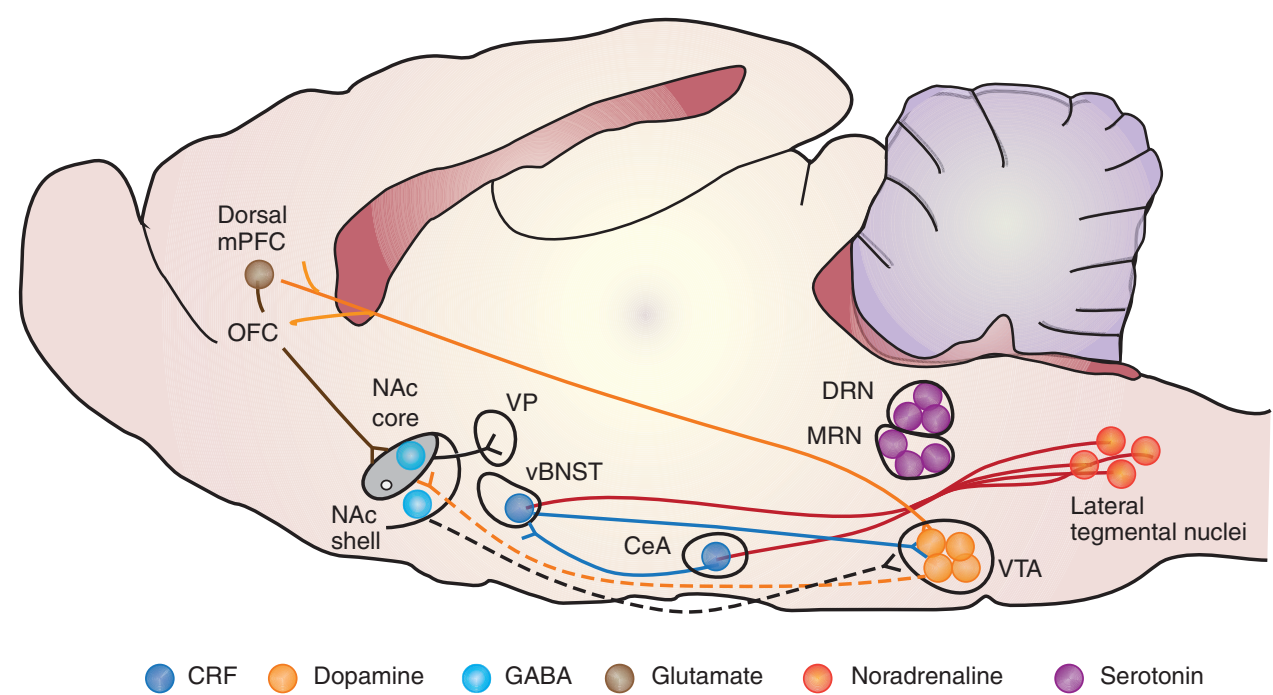

Figure 3. The circuitry of stress-induced reinstatement of drug seeking. The figure depicts brain regions, neuronal projections, and neurotransmitters implicated in stress-induced reinstatement of drug seeking and stress-induced reinstatement of drug CPP (see text for details). Filled lines represent established projections and dashed lines represent putative projections. Abbreviations: CeA, central nucleus of the amygdala; DRN, dorsal raphe nucleus, MRN, median raphe nucleus; mPFC, medial prefrontal cortex; NAc: nucleus accumbens; OFC, orbitofrontal cortex; vBNST, ventral BNST; VP, ventral pallidum; VTA, ventral tegmental area.

(2008) showed that reversible inactivation of the MRN with the GABAa agonist muscimol reinstates alcohol seeking. However, the relevance of this observation to serotonin's role in stress-induced reinstatement is questionable because this effect is not reversed by lesions of serotonin-containing neurons in the brain.

Role of DRN in stress-induced reinstatement of morphine and cocaine CPP. Results from CPP reinstatement studies from the Kirby and Chavkin laboratories implicate the DRN serotonergic cell body region in stress-induced reinstatement. Staub et al (2012) showed that swim stress-induced reinstatement of morphine CPP is associated with increased GABAergic postsynaptic neuronal activity that leads to inhibition of DRN serotonin neurons, and that this inhibitory effect involves local CRF signaling. In a followup study, Li et al (2013) showed that increasing GABAergic inhibitory transmission by DRN muscimol injections reinstates morphine CPP while inhibition of GABAergic neurons by bicuculline (a GABAa receptor antagonist) decreases swim stress-induced reinstatement.

There is also evidence for a role of kappa/dynorphin signaling in DRN in stress-induced reinstatement of cocaine CPP in mice. Land et al (2009) showed that DRN injections of the KOR antagonist Nor-BNI decrease social stressinduced reinstatement of cocaine CPP in mice. Their results from experiments examining the role of kappa/dynorphin in DRN in aversive behavior also suggest that the serotonergic projection from DRN to NAc likely has a role in the local inhibitory effect of Nor-BNI in DRN on stress-induced reinstatement of cocaine CPP; however, this possibility was not empirically tested. In a subsequent study, the Chavkin laboratory showed that KOR-mediated social stress-induced activation of $\mathrm{p} 38$ mitogen-activated protein kinase (MAPK) in DRN serotonergic neurons has a critical role in stressinduced reinstatement of cocaine CPP (Bruchas et al, 2011). In this study, the authors first showed that exposure to social defeat stress, which induces reinstatement of cocaine seeking, activates p38MAPK in DRN, and that this effect is reversed by Nor-BNI and is not observed in KOR knockout mice. They then showed that viral-mediated selective deletion of p38MAPK in DRN serotonin neurons decreases social stressinduced reinstatement of cocaine CPP.

Summary. The results of the studies reviewed above indicate an important role for an interaction between CRF and serotonin in MRN in footshock stress-induced reinstatement of alcohol seeking. There is also evidence for a role of DRN serotonergic neurons, which involves both CRF and kappa/ dynorphin. A question for future research is which serotonergic projection areas contribute to the distinct roles of MRN and DRN in stress-induced reinstatement in the operant model and the CPP model (Figure 3).

\section{TRANSLATIONAL HUMAN RESEARCH}

In this section, we describe results from several human laboratory studies and two double-blind clinical trials in which pharmacological agents that decrease stress-induced reinstatement of drug seeking were tested for their effects on drug craving and relapse in humans. These include the alpha-2 adrenoceptor agonists, clonidine, guanfacine, and lofexidine, the alpha-1 adrenoceptor antagonist, prazosin, and the CRF1 receptor antagonist, pexacerfont. Figures 4 and 5 show comparative data on the effect of alpha-2 adrenoceptor agonists and CRF1 receptor antagonists on 
RATS
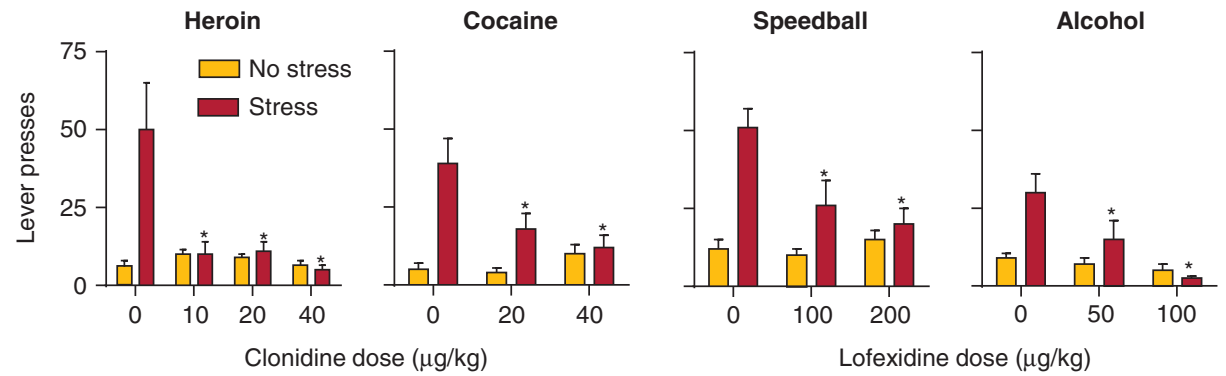

b

HUMANS

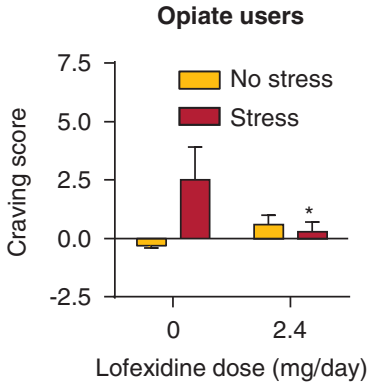

Cocaine users

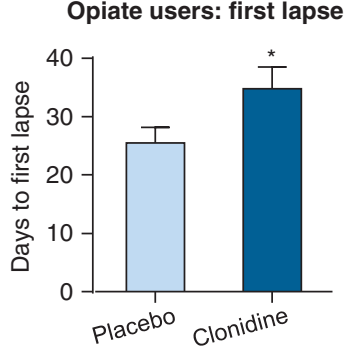

Figure 4. Effects of alpha-2 adrenoceptor agonists on stress-induced reinstatement in rats and stress-induced craving in humans. (a) Rat studies: Data are mean \pm SEM non-reinforced active lever presses after exposure to intermittent footshock or no shock immediately prior to the reinstatement tests in rats with a history of heroin, cocaine, speedball (a heroin-cocaine combination), or alcohol self-administration. The session duration was $3 \mathrm{~h}$ for heroin, cocaine, and speedball, and $1 \mathrm{~h}$ for alcohol. The intermittent footshock duration was $15 \mathrm{~min}$ for heroin, cocaine, and speedball, and 10 min for alcohol. Clonidine and lofexidine were injected 25-45 min before intermittent footshock exposure. (b) Human studies: Left side: Data are mean \pm SEM subjective craving responses assessed on an ordinal Likert scale in opiate users (maintained on naltrexone) or cocaine users who were pretreated with lofexidine or clonidine, respectively, or placebo and exposed to a guided imagery stress or no stress (neutral guided imagery) manipulation. Right side: days to first lapse in human subjects that received chronic placebo or clonidine in a clinical trial. Data were redrawn from Erb et al (2000), Highfield et al (2001), Jobes et al (2011), Kowalczyk et al (2014), Le et al (2005), Shaham et al (2000b), and Sinha et al (2007). *Different from the vehicle (0 dose) in the stress condition or different from the placebo condition, $p<0.05$.

a

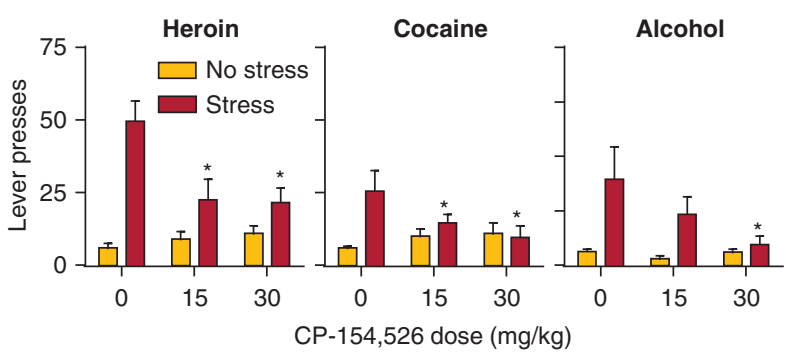

b

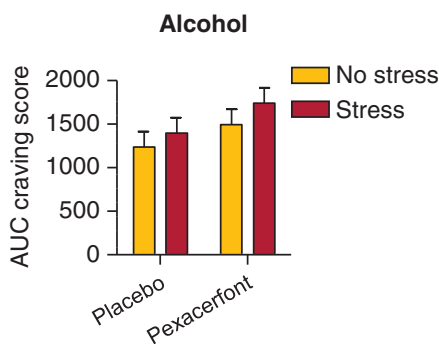

Figure 5. Effects of CRF1 receptor antagonists on stress-induced reinstatement in rats and stress-induced craving in humans. (a) Rat studies: Data are mean \pm SEM non-reinforced active lever presses after exposure to intermittent footshock or no shock immediately prior to the reinstatement tests in rats with a history of heroin, cocaine, or alcohol self-administration. The session duration was $3 \mathrm{~h}$ for heroin and cocaine, and $1 \mathrm{~h}$ for alcohol. The intermittent footshock duration was $15 \mathrm{~min}$ for heroin and $10 \mathrm{~min}$ for cocaine and alcohol. The CRF1 receptor antagonist CP-154,526 was injected 30 min before intermittent footshock exposure. (b) Human study: Data are mean \pm SEM subjective craving responses assessed on an ordinal Likert scale in alcohol users who were pretreated with the CRF1 receptor antagonist pexacerfont and exposed to a guided imagery stress or no stress (neutral guided imagery) manipulation. Data were redrawn from Kwako et al (2015), Le et al (2000) and Shaham et al (1998). *Different from the vehicle (0 dose) in the stress condition, $p<0.05$.

stress-induced reinstatement of drug seeking in rats and stress-induced craving and time to first lapse in humans.

\section{Human Laboratory Studies}

In 1999, Sinha and colleagues introduced a laboratory model to determine, in a cause-effect manner, the effect of stress on drug craving under controlled laboratory conditions (Sinha, 2001; Sinha et al, 1999). They and other investigators showed that certain stressors, including guided imagery stress, the Trier Social Stress Task, and systemic CRF injections induce physiological (eg, increased cortisol release) and psychological (eg, increased anxiety) stress responses and increase self-reports of drug craving (Back et al, 2010; 
Sinha, 2009; Sinha et al, 1999). From the perspective of drug relapse, an important finding from these studies is that physiological and psychological (including drug craving) stress responses in the laboratory predict, to some degree, subsequent drug relapse (Back et al, 2010; Higley et al, 2011; Sinha et al, 2006, 2011a).

Alpha-2 adrenoceptor agonists. In several studies, investigators determined the effects of alpha-2 adrenoceptor agonists on stress- and cue-induced craving in opiate, cocaine, heroin, and nicotine (smokers) users. In an initial preliminary study, Sinha et al (2007) showed that in opiate users maintained on naltrexone, lofexidine treatment $(2.4 \mathrm{mg} /$ day $)$ decreases both stress- and cue-induced opiate craving. Similar findings were observed in a larger sample study with cocaine users in which Jobes et al (2011) showed that clonidine $(0.1$ or $0.2 \mathrm{mg})$ administration decreases stress- and cue-induced cocaine craving (Figure 3 ).

In another study, Fox et al (2012) determined the effects of guanfacine (up to $3 \mathrm{mg} /$ day) on stress-, cue-, and stress+cueinduced drug craving in cocaine-dependent individuals who also use alcohol and nicotine (smokers). They showed that guanfacine decreases stress- and cue-induced nicotine craving. Guanfacine also modestly decreased cue-induced cocaine craving, anxiety, and arousal, but not stress-induced craving. However, the latter negative finding may reflect a floor effect, because the stress manipulation caused a very weak craving response in the placebo group.

More recently, McKee et al (2014) showed that in human smokers guanfacine treatment $(3 \mathrm{mg} /$ day $)$ decreases both stress-induced drug craving and stress-induced smoking in the laboratory. In another study, Fox et al (2014) examined the effect of guanfacine ( 2 or $3 \mathrm{mg} /$ day) on stress-, cue, and stress+cue-induced craving in male and female cocaine users who also use alcohol and nicotine (smokers). A surprising finding in this study was that guanfacine selectively decreased cocaine craving, alcohol craving, anxiety, and negative emotion following exposure to all three experimental conditions in females but not in males. In contrast, guanfacine decreased stress and cue-induced nicotine craving in both males and females. Finally, in a very recent study Moran-Santa Maria et al (2015a) showed that in cocaine users acute administration of guanfacine $(2 \mathrm{mg})$ has no effect on cocaine craving in response to stress, cue, or stress+cue. In interpreting these data, two pharmacological factors should be considered. The first is that, unlike the previous guanfacine studies of Sinha and colleagues in which guanfacine was given chronically for several weeks, in the Moran-Santa Maria et al (2015a) study, the drug was given acutely. The second is that the data of Sinha and colleagues suggest that the minimal effective dose of guanfacine in the laboratory studies is $\sim 3 \mathrm{mg}$, which is higher than the dose used in Moran-Santa Maria et al study.

Findings from three other human laboratory studies in which yohimbine was used to induce drug craving and seeking provide additional support to the translational value of stress-induced reinstatement studies in laboratory animals. In these studies, doses of yohimbine that induced physiological and psychological stress responses increased alcohol craving (Umhau et al, 2011), potentiated cue-induced cocaine craving (an effect that was more pronounced in females), and increased opiate seeking in a choice-based (hydromorphone $v s$ money) progressive ratio task (Greenwald et al, 2013). Thus, despite the interpretation issues related to yohimbine's effects in rat reinstatement studies (Box 2), in humans, the drug induces an aversive stress-like state of which one manifestation is increased drug craving and seeking.

Finally, as discussed elsewhere (Bossert et al, 2013), an unexpected finding in the human studies was that alpha-2 adrenoceptor agonists decreased both stress- and cueinduced drug craving. This was unexpected because in rat studies the alpha-2 adrenoceptor agonists selectively decreased footshock stress-induced reinstatement but not drug priming- or cue-induced reinstatement (Erb et al, 2000; Highfield et al, 2001), but see Smith and Aston-Jones (2011) for different results. A possible account for these different findings is that in rats cue exposure primarily induces an appetitive motivational state (See, 2005) while in humans, cue exposure also induces stress-like physiological and psychological states that are similar to those induced by stress exposure (Sinha et al, 1999, 2000).

Alpha-1 adrenoceptor and CRF1 receptor antagonists. Two studies determined the effects of the alpha- 1 adrenoceptor antagonist prazosin or the CRF1 receptor antagonist pexacerfont on stress- and cue-induced alcohol craving. Fox et al (2012) showed that in alcohol users prazosin $(16 \mathrm{mg} /$ day) decreases stress-induced craving and negative emotions. Prazosin also decreased cue-induced negative emotion self-reports, but had no effect on cue-induced craving. The negative data might be due to a floor effect, because of a weak cue-induced craving in the placebo group.

Most recently, Kwako et al (2015) determined the effects of oral pexacerfont $(300 \mathrm{mg} /$ day for 7 days and $100 \mathrm{mg} /$ day for 23 days) on stress- and cue-induced alcohol craving in 'anxious' alcohol-dependent subjects. This study was inspired by the large and remarkably consistent preclinical literature on the effect of CRF receptor antagonists on escalation of drug intake, stress-like physiological and psychological withdrawal symptoms, and stress-induced reinstatement of drug seeking across drug classes (Heilig and Koob, 2007; Koob, 2008; Shalev et al, 2010; Zorrilla et al, 2013a). In sharp contrast to the preclinical data, pexacerfont treatment had no effect on stress- or cue-induced alcohol craving, emotional responses, or anxiety (Figure 4). Pexacerfont also had no effect on neural responses (fMRI) to alcohol-related or affective-related cues.

\section{Clinical Trials}

The data from the laboratory studies described above provide evidence for the human 'translational' value of the stressinduced reinstatement model. However, from a perspective of human drug relapse, a critical test for the predictive 
validity of the model is whether medications identified in the rat model show efficacy in the drug user's environment (Epstein et al, 2006). Kowalczyk et al (2014) recently determined in heroin users whether the clinical efficacy of buprenorphine would be enhanced by clonidine. In this relapse prevention study, the subjects first received contingency management to facilitate initial abstinence. Subjects who successfully maintained abstinence were randomized to receive clonidine $(0.1 \mathrm{mg}$ for 1 week, $0.2 \mathrm{mg}$ for the next week, and $0.3 \mathrm{mg}$ for the rest of the study, $n=61$ ) or placebo $(n=57)$ for 14 weeks. The main dependent measures were time to lapse (defined as any opiate positive or missed urines) and time to relapse (defined as any consecutive lapses), as well as baseline craving, and stress- and cueinduced craving in the subjects' home environment, as assessed by real-time ecological momentary assessment (EMA) (Epstein et al, 2009). The main findings of the study were that clonidine treatment increased the time to lapse (from 25 to 35 days) (Figure 4) and decreased baseline craving and stress-induced craving. In contrast, clonidine had no effect on relapse rates once a lapse had occurred.

In the context of our review, a study of Krupitsky et al (2013), which likely was not based on the stress-induced reinstatement studies in the animal model, is also relevant. In this 6-month clinical trial, these authors determined whether guanfacine ( $1 \mathrm{mg} /$ day) would decrease relapse rates in opiate users maintained on naltrexone. The main finding was that guanfacine had no effect on relapse rates but decreased selfreports of stress and craving. While the study included a large number of subjects ( $n=75$ per group) and was well designed, a potential methodological issue was the use of a low guanfacine dose $(1 \mathrm{mg})$. The studies described in section 'Human laboratory studies' suggest that the effective dose of guanfacine in the laboratory studies is $\sim 3 \mathrm{mg}$ (Fox et al, 2014; McKee et al, 2014).

\section{Summary}

The results of the human studies with alpha-2 adrenoceptor agonists and prazosin appear to support the translational utility of the stress-induced reinstatement model. However, unlike the uniform effects of these agonists on stress-induced reinstatement in the rat model, the effects in the human studies are more variable, and some of the human studies reported negative results (Krupitsky et al, 2013; Moran-Santa Maria et al, 2015a), possibly due to the use of doses that were lower than those used in the studies that report positive effects. The human studies also suggest potential sex differences in the efficacy of alpha-2 adrenoceptor agonists (Fox et al, 2014), a factor that has not been considered in the preclinical studies. What might account for the more heterogeneous/variable results in the clinical preclinical studies?

We propose that four factors might be particularly important. The first is the fact that rat or mouse studies are invariably performed using highly homogenous subjects of the same or similar age, sex, drug exposure duration, and in many cases likely from a limited number of litters (and therefore a homogenous genetic background). In contrast, the human studies are performed with a highly heterogeneous subject population of different ages, duration of drug use, race, and also includes both sexes. The second factor is the more flexible nature of studies using animal models, which allows investigators to adjust both experimental parameters, including drug doses, to determine the effects of pharmacological agents on reinstatement under more than one experimental set-up. In contrast, human studies are typically performed double-blind from start to end, which increases statistical power but may result in negative data due to two main sources that have a significant role in the studies reviewed above: drug doses that were likely too low and experimental manipulations (stress- or cue-induced reinstatement) that in some studies had minimal effect on craving, making it difficult to detect a reliable effect of the medication. Third, a significant issue in assessing the efficacy of medications to treat drug addiction is compliance (Weiss, 2004), an issue that likely also played a role in the studies reviewed above. Fourth, the different types of stressors used in the preclinical studies (exposure to a physical aversive stimulus such as footshock, restraint, or cold water) vs the stressors used in the clinical studies (exposure to psychological stressors like stress imagery or the Trier Social Stress Task) is an issue to consider in 'translational' studies on stressinduced reinstatement of drug seeking in which different results are observed in human studies vs. animal models.

Finally, the negative results with pexacerfont (Kwako et al, 2015) indicate that it is unrealistic to expect that all potential medications identified in animal models of psychiatric disorders, including the stress-induced reinstatement model, will readily translate to the human condition. However, these negative data are particularly disappointing because, as mentioned above, they are based on unparalleled convergence from multiple animal models of drug addiction and results that were independently demonstrated in multiple laboratories using different drugs of abuse under different experimental conditions (Heilig and Koob, 2007; Koob, 2008; Sarnyai et al, 2001; Shalev et al, 2010).

\section{CONCLUSIONS AND FUTURE DIRECTIONS}

The demonstration that a brief exposure to uncontrollable and unpredictable intermittent footshock stress reinstates heroin seeking in rats (Shaham and Stewart, 1995) has stimulated research by many preclinical investigators on behavioral and neuropharmacological mechanisms of stress-induced reinstatement of drug seeking and CPP. The preclinical model of stress-induced reinstatement and the demonstration that stress can provoke drug craving under controlled experimental conditions (Sinha et al, 1999) have also stimulated translational research to identify potential medications that specifically target stress-induced craving and relapse in humans. In this review, we summarized this field of research to consolidate the current state of knowledge within a single review. The results from the studies reviewed suggest at least four future lines of investigation. 
The first is the investigation of the synaptic and cellular mechanisms of stress-induced reinstatement. Several studies have explored this question for swim stress-induced reinstatement of cocaine seeking in rats (Chirila et al, 2014; Kreibich and Blendy, 2004; Polter et al, 2014) and social defeat-induced reinstatement of cocaine CPP in mice (Bruchas et al, 2010, 2011; Land et al, 2009). At present, however, the synaptic and cellular mechanisms of stressinduced reinstatement are largely unknown.

The second is the investigation of circuitry mechanisms of stress-induced reinstatement, using neuroscience methods that go beyond classical neuropharmacological and neuroanatomical methods. In the 'relapse/reinstatement' field, investigators recently have begun to incorporate modern chemogenetic (Bossert et al, 2011; Cruz et al, 2014; Fanous et al, 2012; Mahler et al, 2014) and optogenetic (Lee et al, 2013; Ma et al, 2014; Stefanik et al, 2013) methods to study brain circuits of context-, cue-, and drug priming-induced reinstatement of drug seeking, but these methods have not yet been used for stress-induced reinstatement.

The third is the study of sex differences in stress-induced reinstatement of drug seeking. In this regard, footshock stressinduced reinstatement of drug seeking is observed in both male and female rats (Shaham and Stewart, 1995). Additionally, recent studies on sex differences and the role of ovarian hormones in stress-induced reinstatement have used yohimbine as a stressor and the results are mixed. Two studies showed that yohimbine effect on reinstatement of cocaine and methamphetamine seeking is somewhat stronger in female rats than in male rats (Anker and Carroll, 2010a; Cox et al, 2013). However, other studies have shown neither sex differences nor a role of ovarian hormones in yohimbineinduced reinstatement of nicotine or palatable food seeking (Cifani et al, 2012; Feltenstein et al, 2012; Pickens et al, 2012). A question for future research is whether sex differences would be observed in the mechanisms that mediate stressinduced reinstatement.

Finally, during human abstinence, stress exposure often occurs in the presence of contexts and cues previously associated with drug use and the drug itself in the case of an initial lapse (Epstein et al, 2009). Human laboratory studies also indicate that stress can potentiate cue-induced drug craving (Fox et al, 2014; George et al, 2008; Moran-Santa Maria et al, 2015b). Additionally, studies using the reinstatement model demonstrate that stress exposure potentiates the response to both cues (Buffalari and See, 2009; Liu and Weiss, 2002b) and drug priming injections (Graf et al, 2013). Thus, from a translational perspective, mechanistic studies on stress-induced potentiation of the response to drug cues or contexts after extinction or without prior extinction may lead to the identification of new targets for developing medications for relapse prevention.

\section{ACKNOWLEDGMENTS}

The writing of this review was supported by extramural (JRM, DAB, and $A L$ ) and intramural (YS) funds from the
National Institute on Drug Abuse, NIH. Dr David Baker and Dr John Mantsch receive compensation from and have financial holdings in Promentis Pharmaceuticals.

\section{FUNDING AND DISCLOSURE}

The authors declare no conflict of interest.

\section{REFERENCES}

Ahmed SH, Koob GF (1997). Cocaine- but not food-seeking behavior is reinstated by stress after extinction. Psychopharmacology 132: 289-295.

Ahmed SH, Walker JR, Koob GF (2000). Persistent increase in the motivation to take heroin in rats with history of drug escalation. Neuropsychopharmacology 22: 413-421

Aldrich JV, Patkar KA, McLaughlin JP (2009). Zyklophin, a systemically active selective kappa opioid receptor peptide antagonist with short duration of action. Proc Natl Acad Sci USA 106: 18396-18401.

Aldrich JV, Senadheera SN, Ross NC, Ganno ML, Eans SO, McLaughlin JP (2013). The macrocyclic peptide natural product $\mathrm{CJ}-15,208$ is orally active and prevents reinstatement of extinguished cocaine-seeking behavior. J Nat Prod 76: 433-438.

Anker JJ, Carroll ME (2010a). Reinstatement of cocaine seeking induced by drugs, cues, and stress in adolescent and adult rats. Psychopharmacology 208: 211-222.

Anker JJ, Carroll ME (2010b). Sex differences in the effects of allopregnanolone on yohimbine-induced reinstatement of cocaine seeking in rats. Drug Alcohol Depend 107: 264-267.

Antelman SM, Levine J, Gershon S (2000). Time-dependent sensitization: the odyssey of a scientific heresy from the laboratory to the door of the clinic. Mol Psychiatry 5: 350-356.

Aston-Jones G, Delfs JM, Druhan J, Zhu Y (1999). The bed nucleus of the stria terminalis: A target site for noradrenergic actions in opiate withdrawal. Ann NY Acad Sci 877: 486-498.

Back SE, Hartwell K, DeSantis SM, Saladin M, McRae-Clark AL, Price KL et al (2010). Reactivity to laboratory stress provocation predicts relapse to cocaine. Drug Alcohol Depend 106: 21-27.

Bale TL, Vale WW (2004). CRF and CRF receptors: role in stress responsivity and other behaviors. Annu Rev Pharmacol Toxicol 44: 525-557.

Bannon MB, Roth RH (1983). Pharmacology of mesocortical dopamine neurons. Pharmacol Rev 35: 53-68.

Beardsley PM, Howard JL, Shelton KL, Carroll FI (2005). Differential effects of the novel kappa opioid receptor antagonist, JDTic, on reinstatement of cocaineseeking induced by footshock stressors vs cocaine primes and its antidepressant-like effects in rats. Psychopharmacology 183: 118-126.

Beardsley PM, Pollard GT, Howard JL, Carroll FI (2010). Effectiveness of analogs of the kappa opioid receptor antagonist (3R)-7-hydroxy-N-((1S)-1-\{[(3R,4R)-4-(3hydroxyphenyl)-3,4-dimethyl-1-pipe ridinyl]methyl\}-2-methylpropyl)-1,2,3,4-tetrahydro-3-isoquinolinecarboxami de (JDTic) to reduce U50,488-induced diuresis and stress-induced cocaine reinstatement in rats. Psychopharmacology 210: 189-198

Blacktop JM, Seubert C, Baker DA, Ferda N, Lee G, Graf EN et al (2011). Augmented cocaine seeking in response to stress or CRF delivered into the ventral tegmental area following long-access self-administration is mediated by CRF receptor type 1 but not CRF receptor type 2. J Neurosci 31: 11396-11403.

Bornstein SR, Webster EL, Torpy DJ, Richman SJ, Mitsiades N, Igel M et al (1998). Chronic effects of a nonpeptide corticotropin-releasing hormone type I receptor antagonist on pituitary-adrenal function, body weight, and metabolic regulation. Endocrinology 139: 1546-1555.

Bossert JM, Ghitza UE, Lu L, Epstein DH, Shaham Y (2005). Neurobiology of relapse to heroin and cocaine seeking: An update and clinical implications. Eur J Pharmacol 526: 36-50.

Bossert JM, Marchant NJ, Calu DJ, Shaham Y (2013). The reinstatement model of drug relapse: recent neurobiological findings, emerging research topics, and translational research. Psychopharmacology (Berl) 229: 453-476.

Bossert JM, Stern AL, Theberge FR, Cifani C, Koya E, Hope BT et al (2011). Ventral medial prefrontal cortex neuronal ensembles mediate context-induced relapse to heroin. Nat Neurosci 14: 420-422.

Bouton ME, King DA (1983). Contextual control of the extinction of conditioned fear: tests for the associative value of the context. J Exp Psychol Anim Behav Process 9: 248-265. 
Bouton ME, Swartzentruber D (1991). Sources of relapse after extinction in Pavlovian and instrumental learning. Clin Psychol Rev 11: 123-140.

Boutrel B, Kenny PJ, Specio SE, Martin-Fardon R, Markou A, Koob GF et al (2005). Role for hypocretin in mediating stress-induced reinstatement of cocaine-seeking behavior. Proc Natl Acad Sci USA 102: 19168-19173.

Bremner JD, Krystal JH, Southwick SM, Charney DS (1996a). Noradrenergic mechanisms in stress and anxiety: I. preclinical studies. Synapse 23: 28-38.

Bremner JD, Krystal JH, Southwick SM, Charney DS (1996b). Noradrenergic mechanisms in stress and anxiety: II. clinical studies. Synapse 23: 39-51.

Briand LA, Vassoler FM, Pierce RC, Valentino RJ, Blendy JA (2010). Ventral tegmental afferents in stress-induced reinstatement: the role of cAMP response element-binding protein. J Neurosci 30: 16149-16159.

Brown ZJ, Kupferschmidt DA, Erb S (2012). Reinstatement of cocaine seeking in rats by the pharmacological stressors, corticotropin-releasing factor and yohimbine: role for D1/5 dopamine receptors. Psychopharmacology (Berl) 224: 431-440.

Brown ZJ, Tribe E, D'Souza N A, Erb S (2009). Interaction between noradrenaline and corticotrophin-releasing factor in the reinstatement of cocaine seeking in the rat. Psychopharmacology 203: 121-130.

Bruchas MR, Land BB, Chavkin C (2010). The dynorphin/kappa opioid system as a modulator of stress-induced and pro-addictive behaviors. Brain Res 1314: 44-55.

Bruchas MR, Schindler AG, Shankar H, Messinger DI, Miyatake M, Land BB et al (2011). Selective p38alpha MAPK deletion in serotonergic neurons produces stress resilience in models of depression and addiction. Neuron 71: 498-511.

Buczek Y, Le AD, Wang A, Stewart J, Shaham Y (1999). Stress reinstates nicotine seeking but not sucrose solution seeking in rats. Psychopharmacology 144: 183-188.

Buffalari DM, Baldwin CK, See RE (2012). Treatment of cocaine withdrawal anxiety with guanfacine: relationships to cocaine intake and reinstatement of cocaine seeking in rats. Psychopharmacology (Berl) 223: 179-190.

Buffalari DM, See RE (2009). Footshock stress potentiates cue-induced cocaineseeking in an animal model of relapse. Physiol Behav 98: 614-617.

Buffalari DM, See RE (2011). Inactivation of the bed nucleus of the stria terminalis in an animal model of relapse: effects on conditioned cue-induced reinstatement and its enhancement by yohimbine. Psychopharmacology 213: 19-27.

Cabib S, Imperato A (1996). Stress, depression and the mesolimbic dopamine system. Psychopharamacology 128: 331-342.

Calu DJ, Chen YW, Kawa AB, Nair SG, Shaham Y (2014). The use of the reinstatement model to study relapse to palatable food seeking during dieting. Neuropharmacology 76: 395-406.

Calu DJ, Kawa AB, Marchant NJ, Navarre BM, Henderson MJ, Chen B et al (2013). Optogenetic inhibition of dorsal medial prefrontal cortex attenuates stressinduced reinstatement of palatable food seeking in female rats. J Neurosci 33: 214-226.

Cannon WB (1935). Stresses and strains of homeostasis. Am J Med Sci 189: 1-14.

Capriles N, Rodaros D, Sorge RE, Stewart J (2003). A role for the prefrontal cortex in stress- and cocaine-induced reinstatement of cocaine seeking in rats. Psychopharmacology 168: 66-74.

Carey AN, Borozny K, Aldrich JV, McLaughlin JP (2007). Reinstatement of cocaine place-conditioning prevented by the peptide kappa-opioid receptor antagonist arodyn. Eur J Pharmacol 569: 84-89.

Carroll ME (1985). The role of food deprivation in the maintenance and reinstatement of cocaine-seeking behavior in rats. Drug Alcohol Depend 16: 95-109.

Cassell MD, Freedman LJ, Shi C (1999). The intrinsic organization of the central extended amygdala. Ann NY Acad Sci 877: 217-241.

Chaouloff $F$ (1993). Physiopharamcological interactions between stress hormones and central serotonergic systems. Brain Res Rev 18: 1-32.

Chen NA, Jupp B, Sztainberg Y, Lebow M, Brown RM, Kim JH et al (2014a). Knockdown of CRF1 receptors in the ventral tegmental area attenuates cue- and acute food deprivation stress-induced cocaine seeking in mice. J Neurosci 34: 11560-11570.

Chen YW, Fiscella KA, Bacharach SZ, Calu DJ (2014b). Effect of cafeteria diet history on cue-, pellet-priming-, and stress-induced reinstatement of food seeking in female rats. PLoS One 9: e102213.

Chen YW, Fiscella KA, Bacharach SZ, Tanda G, Shaham Y, Calu DJ (2014c). Effect of yohimbine on reinstatement of operant responding in rats is dependent on cue contingency but not food reward history. Addict Biol (in press).

Chirila AM, Brown TE, Bishop RA, Bellono NW, Pucci FG, Kauer JA (2014). Longterm potentiation of glycinergic synapses triggered by interleukin 1 beta. Proc Natl Acad Sci USA 111: 8263-8268.

Chrousos GP, Gold PW (1992). The concepts of stress and stress system disorders. Overview of physical and behavioral homeostasis. JAMA 267: 1244-1452.

Ciccocioppo R, Stopponi S, Economidou D, Kuriyama M, Kinoshita H, Heilig M et al (2014). Chronic treatment with novel brain-penetrating selective NOP receptor agonist MT-7716 reduces alcohol drinking and seeking in the rat. Neuropsychopharmacology 39: 2601-2610.

Cifani C, Koya E, Navarre BM, Calu DJ, Baumann MH, Marchant NJ et al (2012). Medial prefrontal cortex neuronal activation and synaptic alterations after stressinduced reinstatement of palatable food seeking: a study using c-fos-GFP transgenic female rats. J Neurosci 32: 8480-8490.

Cippitelli A, Brunori G, Gaiolini KA, Zaveri NT, Toll L (2015). Pharmacological stress is required for the anti-alcohol effect of the alpha3beta4* nAChR partial agonist AT-1001. Neuropharmacology 93: 229-236.

Cippitelli A, Cannella N, Braconi S, Duranti A, Tontini A, Bilbao A et al (2008). Increase of brain endocannabinoid anandamide levels by FAAH inhibition and alcohol abuse behaviours in the rat. Psychopharmacology (Berl) 198: 449-460.

Cippitelli A, Rezvani AH, Robinson JE, Eisenberg L, Levin ED, Bonaventure P et al (2011). The novel, selective, brain-penetrant neuropeptide $Y$ Y2 receptor antagonist, JNJ-31020028, tested in animal models of alcohol consumption, relapse, and anxiety. Alcohol 45: 567-576.

Cleck JN, Ecke LE, Blendy JA (2008). Endocrine and gene expression changes following forced swim stress exposure during cocaine abstinence in mice. Psychopharmacology (Berl) 201: 15-28.

Cohen F, Horowitz MJ, Lazarus RS, Moos RH, Robbins LN, Rose RM et al (1982). Panel report on psychosocial and modifiers of stress. In: Eliott GR, Eisdorfer C (eds). Stress and Human Health. Springer Publishing Co.: New York. pp 147-188.

Cohen S, Evans GW, Stokols D, Krantz DS (1986). Behavior, health, and environmental stress. Plenum Press: New York.

Conrad KL, McCutcheon JE, Cotterly LM, Ford KA, Beales M, Marinelli M (2010). Persistent increases in cocaine-seeking behavior after acute exposure to cold swim stress. Biol Psychiatry 68: 303-305.

Cox BM, Young AB, See RE, Reichel CM (2013). Sex differences in methamphetamine seeking in rats: impact of oxytocin. Psychoneuroendocrinology 38 : 2343-2353.

Cruz FC, Babin KR, Leao RM, Goldart EM, Bossert JM, Shaham Y et al (2014). Role of nucleus accumbens shell neuronal ensembles in context-induced reinstatement of cocaine-seeking. J Neurosci 34: 7437-7446.

Dallman MF, Akana SF, Levin N, Walker CD, Bradbury MJ, Suemaru S et al (1995). Corticosteroids and the control of function in the hypothalamo-pituitary-adrenal (HPA) axis. Ann NY Acad Sci 746: 22-31.

Davis M, Walker DL, Lee Y (1997). Roles of the amygdala and bed nucleus of the stria terminalis in fear and anxiety measured with the acoustic startle reflex. Possible relevance to PTSD. Ann NY Acad Sci 821: 305-331.

Davis M, Walker DL, Miles L, Grillon C (2010). Phasic vs sustained fear in rats and humans: role of the extended amygdala in fear vs anxiety. Neuropsychopharmacology 35: 105-135.

de Guglielmo G, Cippitelli A, Somaini L, Gerra G, Li H, Stopponi S et al (2013). Pregabalin reduces cocaine self-administration and relapse to cocaine seeking in the rat. Addict Biol 18: 644-653.

de Guglielmo G, Martin-Fardon R, Teshima K, Ciccocioppo R, Weiss F (2014). MT-7716, a potent NOP receptor agonist, preferentially reduces ethanol seeking and reinforcement in post-dependent rats. Addict Biol.

Deroche V, Marinelli M, Le Moal M, Piazza PV (1997). Glucocorticoids and behavioral effects of psychostimulants. II: cocaine intravenous self-administration and reinstatement depend on glucocorticoid levels. J Pharmacol Exp Ther 281: 1401-1407.

Deutch AY, Roth RH (1990). The determinants of stress-induced activation of the prefrontal cortical dopamine system. Prog Brain Res 85: 367-403.

Deutch JA, Howarth Cl (1962). Evocation by fear of a habit learned for electrical stimulation of the brain. Science 130: 1057-1058.

Eans SO, Ganno ML, Reilley KJ, Patkar KA, Senadheera SN, Aldrich JV et al (2013). The macrocyclic tetrapeptide [D-Trp]CJ-15,208 produces short-acting kappa opioid receptor antagonism in the CNS after oral administration. $\mathrm{Br} J$ Pharmacol 169: 426-436.

Economidou D, Mattioli L, Ubaldi M, Lourdusamy A, Soverchia L, Hardiman G et al (2007). Role of cannabinoidergic mechanisms in ethanol self-administration and ethanol seeking in rat adult offspring following perinatal exposure to Delta(9)tetrahydrocannabinol. Toxicol Appl Pharmacol 223: 73-85.

Enrico P, Bouma M, de Vries JB, Westerink BH (1998). The role of afferents to the ventral tegmental area in the handling stress-induced increase in the release of dopamine in the medial prefrontal cortex: a dual-probe microdialysis study in the rat brain. Brain Res 779: 205-213.

Epstein D, Preston K, Stewart J, Shaham Y (2006). Toward a model of drug relapse: an assessment of the validity of the reinstatement procedure. Psychopharmacology 189: 1-16.

Epstein DH, Willner-Reid J, Vahabzadeh M, Mezghanni M, Lin JL, Preston KL (2009). Real-time electronic diary reports of cue exposure and mood in the hours before cocaine and heroin craving and use. Arch Gen Psychiatry 66: 88-94. 
Erb S, Hitchcott PK, Rajabi H, Mueller D, Shaham Y, Stewart J (2000). Alpha-2 adrenergic agonists block stress-induced reinstatement of cocaine seeking. Neuropsychopharmacology 23: 138-150.

Erb S, Petrovic A, Yi D, Kayyali H (2006). Central injections of CRF reinstate cocaine seeking in rats after postinjection delays of up to $3 \mathrm{~h}$ : an influence of time and environmental context. Psychopharmacology 187: 112-120.

Erb S, Salmaso N, Rodaros D, Stewart J (2001a). A role for the CRF-containing pathway projecting from central nucleus of the amygdala to bed nucleus of the stria terminalis in the stress-induced reinstatement of cocaine seeking in rats. Psychopharmacology 158: 360-365.

Erb S, Shaham Y, Stewart J (1996). Stress reinstates cocaine-seeking behavior after prolonged extinction and drug-free periods. Psychopharmacology 128: 408-412.

Erb S, Shaham Y, Stewart J (1998). The role of corticotropin-releasing factor and corticosterone in stress- and cocaine-induced relapse to cocaine seeking in rats. J Neurosci 18: 5529-5536.

Erb S, Shaham Y, Stewart J (2001b). Stress-induced relapse to drug seeking in the rat: Role of the bed nucleus of the stria terminalis and amygdala. Stress 4 : 289-303.

Erb S, Stewart J (1999). A role for the bed nucleus of the stria terminalis, but not the amygdala, in the effects of corticotropin-releasing factor on stress-induced reinstatement of cocaine seeking. J Neurosci 19: RC35.

Ettenberg A (2009). The runway model of drug self-administration. Pharmacol Biochem Behav 91: 271-277.

Ettenberg A, MacConell LA, Geist TD (1996). Effects of haloperidol in a responsereinstatement model of heroin relapse. Psychopharmacology (Berl) 124: 205-210.

Fanous S, Goldart EM, Theberge FR, Bossert JM, Shaham Y, Hope BT (2012). Role of orbitofrontal cortex neuronal ensembles in the expression of incubation of heroin craving. J Neurosci 32: 11600-11609.

Feltenstein MW, Ghee SM, See RE (2012). Nicotine self-administration and reinstatement of nicotine-seeking in male and female rats. Drug Alcohol Depend 121: $240-246$

Feltenstein MW, See RE (2006). Potentiation of cue-induced reinstatement of cocaine-seeking in rats by the anxiogenic drug yohimbine. Behav Brain Res 174: 1-8.

Figueroa-Guzman Y, Mueller C, Vranjkovic O, Wisniewski S, Yang Z, Li SJ et al (2010). Oral administration of levo-tetrahydropalmatine attenuates reinstatement of extinguished cocaine seeking by cocaine, stress or drug-associated cues in rats. Drug Alcohol Depend 116: 72-79.

Flavin SA, Winder DG (2013). Noradrenergic control of the bed nucleus of the stria terminalis in stress and reward. Neuropharmacology 70: 324-330.

Fletcher PJ, Rizos Z, Sinyard J, Tampakeras M, Higgins GA (2008). The 5-HT(2C) receptor agonist Ro60-0175 reduces cocaine self-administration and reinstatement induced by the stressor yohimbine, and contextual cues. Neuropsychopharmacology 33: 1402-1412.

Ford CP, Beckstead MJ, Williams JT (2007). Kappa opioid inhibition of somatodendritic dopamine inhibitory postsynaptic currents. I Neurophysiol 97: 883-891.

Fox HC, Morgan PT, Sinha R (2014). Sex differences in guanfacine effects on drug craving and stress arousal in cocaine-dependent individuals. Neuropsychopharmacology 39: 1527-1537.

Fox HC, Seo D, Tuit K, Hansen J, Kimmerling A, Morgan PT et al (2012). Guanfacine effects on stress, drug craving and prefrontal activation in cocaine dependent individuals: preliminary findings. J Psychopharmacol 26: 958-972.

Fritschy JM, Grzanna R (1991). Selective effects of DSP-4 on locus coeruleus axons: are there pharmacologically different types of noradrenergic axons in the central nervous system? Prog Brain Res 88: 257-268.

Funk D, Coen K, Le AD (2014). The role of kappa opioid receptors in stress-induced reinstatement of alcohol seeking in rats. Brain Behav 4: 356-367.

Funk D, Harding S, Juzytsch W, Le AD (2005). Effects of unconditioned and conditioned social defeat on alcohol self-administration and reinstatement of alcohol seeking in rats. Psychopharmacology 183: 341-349.

Gehlert DR, Cippitelli A, Thorsell A, Le AD, Hipskind PA, Hamdouchi C et al (2007). 3-(4-Chloro-2-morpholin-4-yl-thiazol-5-yl)-8-(1-ethylpropyl)-2,6-dimethyl- imidazo [1,2-b]pyridazine: a novel brain-penetrant, orally available corticotropin-releasing factor receptor 1 antagonist with efficacy in animal models of alcoholism. J Neurosci 27: 2718-2726.

Geisler S, Derst C, Veh RW, Zahm DS (2007). Glutamatergic afferents of the ventral tegmental area in the rat. J Neurosci 27: 5730-5743.

George DT, Gilman J, Hersh J, Thorsell A, Herion D, Geyer C et al (2008). Neurokinin 1 receptor antagonism as a possible therapy for alcoholism. Science 319: 1536-1539.

Georges F, Aston-Jones G (2002). Activation of ventral tegmental area cells by the bed nucleus of the stria terminalis: a novel excitatory amino acid input to midbrain dopamine neurons. J Neurosci 22: 5173-5187.
Gerfen CR (1992). The neostriatal mosaic: multiple levels of compartmenta organization in the basal ganglia. Annu Rev Neurosci 15: 285-320.

Ghitza UE, Gray SM, Epstein DH, Rice KC, Shaham Y (2006). The anxiogenic drug yohimbine reinstates palatable food seeking in a rat relapse model: a role of CRF (1) receptors. Neuropsychopharmacology 31: 2188-2196.

Glass DC, Singer JE (1972). Urban Stress: Experiments on Noise and Social Stressors. Academic Press: New York.

Glowa JR, Barrett JE, Gold PW (1992). Effects of corticotropin releasing hormone on appetitive behaviors. Peptides 13: 609-621.

Gold RM (1966). Aphagia and adipsia produced by unilateral hypothalamic lesions in rats. Am J Physiol 211: 1274-1276.

Graf EN, Hoks MA, Baumgardner J, Sierra J, Vranjkovic O, Bohr C et al (2011). Adrenal activity during repeated long-access cocaine self-administration is required for later CRF-Induced and CRF-dependent stressor-induced reinstatement in rats. Neuropsychopharmacology 36: 1444-1454.

Graf EN, Wheeler RA, Baker DA, Ebben AL, Hill JE, McReynolds JR et al (2013). Corticosterone acts in the nucleus accumbens to enhance dopamine signaling and potentiate reinstatement of cocaine seeking. J Neurosci 33: 11800-11810,

Gray JA (1987). The Psychology of Fear and Stress2nd edn.Cambridge University Press: New York.

Graziane NM, Polter AM, Briand LA, Pierce RC, Kauer JA (2013). Kappa opioid receptors regulate stress-induced cocaine seeking and synaptic plasticity. Neuron 77: 942-954.

Greenwald MK, Lundahl LH, Steinmiller CL (2013). Yohimbine increases opioidseeking behavior in heroin-dependent, buprenorphine-maintained individuals. Psychopharmacology 225: 811-824.

Grella SL, Funk D, Coen K, Li Z, Le AD (2014). Role of the kappa-opioid receptor system in stress-induced reinstatement of nicotine seeking in rats. Behav Brain Res 265: 188-197.

Grimwood S, Lu Y, Schmidt AW, Vanase-Frawley MA, Sawant-Basak A, Miller E et al (2011). Pharmacological characterization of 2-methyl-N-((2'-(pyrrolidin-1-ylsulfonyl)biphenyl-4-yl)methyl)propan-1-ami ne (PF-04455242), a high-affinity antagonist selective for kappa-opioid receptors. J Pharmacol Exp Ther 339: 555-566.

Hale MW, Lowry CA (2011). Functional topography of midbrain and pontine serotonergic systems: implications for synaptic regulation of serotonergic circuits. Psychopharmacology (Berl) 213: 243-264.

Hansson AC, Cippitelli A, Sommer WH, Fedeli A, Bjork K, Soverchia L et al (2006). Variation at the rat Crhr1 locus and sensitivity to relapse into alcohol seeking induced by environmental stress. Proc Natl Acad Sci USA 103: 15236-15241.

Haynes R (1990). Adrenocorticotropic hormones: adrenocortical steroids and their synthetic analogs; inhibitors of the synthesis and actions of adrenocortical hormonesIn:Gilman A, Rall T, Nies A, Taylor P (eds) Goodman \& Gilman's the Pharmacological Basis of Therapeutics8th edn.Pergamon Press: New York. pp 1431-1462.

Heilig M, Koob GF (2007). A key role for corticotropin-releasing factor in alcohol dependence. Trends Neurosci 30: 399-406.

Highfield D, Clements A, Shalev U, McDonald R, Featherstone R, Stewart J et al (2000). Involvement of the medial septum in stress-induced relapse to heroin seeking in rats. Eur J Neurosci 12: 1705-1713.

Highfield D, Mead A, Grimm JW, Rocha BA, Shaham Y (2002). Reinstatement of cocaine seeking in mice: effects of cocaine priming, cocaine cues and food deprivation. Psychopharmacology 161: 417-424.

Highfield D, Yap J, Grimm JW, Shalev U, Shaham Y (2001). Repeated lofexidine treatment attenuates stress-induced, but not drug cues-induced reinstatement of a heroin-cocaine mixture (speedball) seeking in rats. Neuropsychopharmacology 25: 320-331.

Higley AE, Crane NA, Spadoni AD, Quello SB, Goodell V, Mason BJ (2011). Craving in response to stress induction in a human laboratory paradigm predicts treatment outcome in alcohol-dependent individuals. Psychopharmacology 218: 121-129.

Holdstock T (1967). Effects of septal stimulation in rats on heart rate and galvanic skin response. Psychonom Sci 9: 38.

Hunt WA, Barnett LW, Branch LG (1971). Relapse rates in addiction programs. $J$ Clin Psychol 27: 455-456.

Jackson KJ, McLaughlin JP, Carroll FI, Damaj MI (2013). Effects of the kappa opioid receptor antagonist, norbinaltorphimine, on stress and drug-induced reinstatement of nicotine-conditioned place preference in mice. Psychopharmacology 226: 763-768.

Jenkins J, Meakin J, Nelson D, Thorn G (1958). Inhibition of adrenal steroid 11oxygenation in the dog. Science 128: 478-480.

Jobes ML, Ghitza UE, Epstein DH, Phillips KA, Heishman SJ, Preston KL (2011). Clonidine blocks stress-induced craving in cocaine users. Psychopharmacology 218: 83-88

Kalivas PW, Duffy P, Latimer LG (1987). Neurochemical and behavioral effects of corticotropin-releasing factor in the ventral tegmental area of the rat. J Pharmacol Exp Ther 242: 757-763. 
Kalivas PW, McFarland K (2003). Brain circuitry and the reinstatement of cocaineseeking behavior. Psychopharmacology 168: 44-56.

Kalivas PW, Stewart J (1991). Dopamine transmission in the initiation and expression of drug- and stress-induced sensitization of motor activity. Brain Res Rev 16: 223-244.

Khantzian EJ (1985). The self-medication hypothesis of addictive disorders: focus on heroin and cocaine dependence. Am J Psychiatry 142: 1259-1264.

Kirby LG, Rice KC, Valentino RJ (2000). Effects of corticotropin-releasing factor on neuronal activity in the serotonergic dorsal raphe nucleus. Neuropsychopharmacology 22: 148-162.

Koob GF (2008). A role for brain stress systems in addiction. Neuron 59: 11-34.

Kosten TR, Rounsaville BJ, Kleber HD (1986). A 2.5-year follow-up of depression, life crises, and treatment effects on abstinence among opioid addicts. Arch Gen Psychiatry 43: 733-738.

Kowalczyk WJ, Phillips KA, Jobes ML, Kennedy AP, Ghitza UE, Agage DA et al (2014). Clonidine maintenance prolongs opioid abstinence and decouples stress from craving in daily life: a randomized controlled trial with ecological momentary assessment. Am J Psychiatry (in press).

Kreibich AS, Blendy JA (2004). cAMP response element-binding protein is required for stress but not cocaine-induced reinstatement. J Neurosci 24: 6686-6692.

Krupitsky E, Zvartau E, Blokhina E, Verbitskaya E, Tsoy M, Wahlgren V et al (2013). Naltrexone with or without guanfacine for preventing relapse to opiate addiction in St.-Petersburg, Russia. Drug Alcohol Depend 132: 674-680.

Kupferschmidt DA, Brown ZJ, Erb S (2011). A procedure for studying the footshockinduced reinstatement of cocaine seeking in laboratory rats. J Vis Exp pii 2265.

Kvetnansky R, Sabban EL, Palkovits M (2009). Catecholaminergic systems in stress: structural and molecular genetic approaches. Physiol Rev 89: 535-606.

Kwako LE, Spagnolo PA, Schwandt ML, Thorsell A, George DT, Momenan R et al (2015). The corticotropin releasing hormone-1 $(\mathrm{CRH} 1)$ receptor antagonist pexacerfont in alcohol dependence: a randomized controlled experimental medicine study. Neuropsychopharmacology 40: 1053-1063.

Land BB, Bruchas MR, Schattauer S, Giardino WJ, Aita M, Messinger D et al (2009). Activation of the kappa opioid receptor in the dorsal raphe nucleus mediates the aversive effects of stress and reinstates drug seeking. Proc Natl Acad Sci USA 106: 19168-19173.

Le AD, Funk D, Harding S, Juzytsch W, Fletcher PJ (2009). The role of noradrenaline and 5-hydroxytryptamine in yohimbine-induced increases in alcohol-seeking in rats. Psychopharmacology 204: 477-488.

Le AD, Funk D, Harding S, Juzytsch W, Fletcher PJ, Shaham Y (2006). Effects of dexfenfluramine and 5-HT3 receptor antagonists on stress-induced reinstatement of alcohol seeking in rats. Psychopharmacology (Berl) 186: 82-92.

Le AD, Funk D, Harding S, Juzytsch W, Li Z, Fletcher PJ (2008). Intra-median raphe nucleus (MRN) infusions of muscimol, a GABA-A receptor agonist, reinstate alcohol seeking in rats: role of impulsivity and reward. Psychopharmacology 195: 605-615.

Le AD, Funk D, Juzytsch W, Coen K, Navarre BM, Cifani C et al (2011). Effect of prazosin and guanfacine on stress-induced reinstatement of alcohol and food seeking in rats. Psychopharmacology (Berl) 218: 89-99.

Le AD, Harding S, Juzytsch W, Fletcher PJ, Shaham Y (2002). The role of corticotropin-releasing factor in the median raphe in relapse to alcohol seeking in rats. J Neurosci 22: 7844-7849.

Le AD, Harding S, Juzytsch W, Funk D, Shaham Y (2005). Role of alpha-2 adrenoceptors in stress-induced reinstatement of alcohol seeking and alcohol self-administration in rats. Psychopharmacology 179: 366-373.

Le AD, Harding S, Juzytsch W, Watchus J, Shalev U, Shaham Y (2000). The role of corticotropin-releasing factor in stress-induced relapse to alcohol-seeking behavior in rats. Psychopharmacology 150: 317-324.

Le AD, Poulos CX, Harding S, Watchus J, Juzytsch W, Shaham Y (1999). Effects of naltrexone and fluoxetine on alcohol self-administration and reinstatement of alcohol seeking induced by priming injections of alcohol and exposure to stress. Neuropsychopharmacology 21: 435-444.

Le AD, Quan B, Juzytch W, Fletcher PJ, Joharchi N, Shaham Y (1998). Reinstatement of alcohol-seeking by priming injections of alcohol and exposure to stress in rats. Psychopharmacology 135: 169-174.

LeDoux JE (2000). Emotion circuits in the brain. Annu Rev Neurosci 23: 155-184.

Lee B, Tiefenbacher S, Platt DM, Spealman RD (2004). Pharmacological blockade of alpha(2)-arenoceptors induces reinstatement of cocaine-seeking behavior in squirrel monkeys. Neuropsychopharmacology 29: 686-693

Lee BR, Ma YY, Huang YH, Wang X, Otaka M, Ishikawa M et al (2013). Maturation of silent synapses in amygdala-accumbens projection contributes to incubation of cocaine craving. Nat Neurosci 16: 1644-1651.

Leri F, Flores J, Rodaros D, Stewart J (2002). Blockade of stress-induced, but not cocaine-induced reinstatement, by infusion of noradrenergic antagonists into the bed nucleus of the stria terminalis or the central nucleus of the amygdala. J Neurosci 22: 5713-5718.
Lewis BL, O'Donnell P (2000). Ventral tegmental area afferents to the prefrontal cortex maintain membrane potential 'up' states in pyramidal neurons via $D(1)$ dopamine receptors. Cereb Cortex 10: 1168-1175.

Li C, Staub DR, Kirby LG (2013). Role of GABAA receptors in dorsal raphe nucleus in stress-induced reinstatement of morphine-conditioned place preference in rats. Psychopharmacology 230: 537-545.

Liu D, Weiss F (2002a). Additive effect of stress and drug cues on reinstatement of ethanol seeking: exacerbation by history of dependence and role of concurrent activation of corticotropin-releasing factor and opioid mechanisms. J Neurosci 22: 7856-7861.

Liu X, Weiss F (2002b). Additive effect of stress and drug cues on reinstatement of ethanol seeking: exacerbation by history of dependence and role of concurrent activation of corticotropin-releasing factor and opioid mechanisms. J Neurosci 22: 7856-7861.

Liu X, Weiss F (2003). Stimulus conditioned to foot-shock stress reinstates alcoholseeking behavior in an animal model of relapse. Psychopharmacology 168: 184-191.

Lu L, Ceng X, Huang M (2000). Corticotropin-releasing factor receptor type I mediates stress-induced relapse to opiate dependence in rats. Neuroreport 11: 2373-2378.

Lu L, Liu D, Ceng X (2001). Corticotropin-releasing factor receptor type 1 mediates stress-induced relapse to cocaine-conditioned place preference in rats. Eur J Pharmacol 415: 203-208.

Lu L, Shepard JD, Scott Hall F, Shaham Y (2003). Effect of environmental stressors on opiate and psychostimulant reinforcement, reinstatement and discrimination in rats: a review. Neurosci Biobehav Rev 27: 457-491.

Lu L, Zhang B, Liu Z, Zhang Z (2002). Reactivation of cocaine conditioned place preference induced by stress is reversed by cholecystokinin-B receptors antagonist in rats. Brain Res 954: 132-140.

Ma YY, Chu NN, Guo CY, Han JS, Cui CL (2007). NR2B-containing NMDA receptor is required for morphine-but not stress-induced reinstatement. Exp Neurol 203: 309-319.

Ma YY, Lee BR, Wang X, Guo C, Liu L, Cui R et al (2014). Bidirectional modulation of incubation of cocaine craving by silent synapse-based remodeling of prefrontal cortex to accumbens projections. Neuron 83: 1453-1467.

Mahler SV, Moorman DE, Feltenstein MW, Cox BM, Ogburn KB, Bachar M et al (2013). A rodent "self-report" measure of methamphetamine craving? Rat ultrasonic vocalizations during methamphetamine self-administration, extinction, and reinstatement. Behav Brain Res 236: 78-89.

Mahler SV, Vazey EM, Beckley JT, Keistler CR, McGlinchey EM, Kaufling J et al (2014). Designer receptors show role for ventral pallidum input to ventral tegmental area in cocaine seeking. Nat Neurosci 17: 577-585.

Maier SF (1984). Learned helplessness and animal models of depression. Prog Neuropsychopharmacol Biol Psychiatry 8: 435-446.

Maier SF, Watkins LR (2005). Stressor controllability and learned helplessness: the roles of the dorsal raphe nucleus, serotonin, and corticotropin-releasing factor. Neurosci Biobehav Rev 29: 829-841.

Mantsch JR, Baker DA, Francis DM, Katz ES, Hoks MA, Serge JP (2008). Stressorand corticotropin releasing factor-induced reinstatement and active stress-related behavioral responses are augmented following long-access cocaine selfadministration by rats. Psychopharmacology 195: 591-603.

Mantsch JR, Goeders NE (1999). Ketoconazole blocks the stress-induced reinstatement of cocaine-seeking behavior in rats: relationship to the discriminative stimulus effects of cocaine. Psychopharmacology 142: 399-407.

Mantsch JR, Vranjkovic O, Twining RC, Gasser PJ, McReynolds JR, Blacktop JM (2014). Neurobiological mechanisms that contribute to stress-related cocaine use. Neuropharmacology 76 Pt B: 383-394.

Mantsch JR, Weyer A, Vranjkovic O, Beyer CE, Baker DA, Caretta H (2010). Involvement of noradrenergic neurotransmission in the stress- but not cocaineinduced reinstatement of extinguished cocaine-induced conditioned place preference in mice: role for beta-2 adrenergic receptors. Neuropsychopharmacology 35: 2165-2178.

Marchant NJ, Kaganovsky K, Shaham Y, Bossert JM (2014). Role of corticostriatal circuits in context-induced reinstatement of drug seeking. Brain Res (in press).

Margolis EB, Hjelmstad GO, Bonci A, Fields HL (2003). Kappa-opioid agonists directly inhibit midbrain dopaminergic neurons. J Neurosci 23: 9981-9986.

Maric T, Sedki F, Chafetz D, Schoela N, Shalev U (2011). A role for neuropeptide $Y$ Y5 but not the Y1-receptor subtype in food deprivation-induced reinstatement of heroin seeking in the rat. Psychopharmacology (Berl) 218: 693-701.

Marinelli PW, Funk D, Juzytsch W, Harding S, Rice KC, Shaham Y et al (2007). The CRF(1) receptor antagonist antalarmin attenuates yohimbine-induced increases in operant alcohol self-administration and reinstatement of alcohol seeking in rats. Psychopharmacology 195: 345-355.

Martin-Fardon R, Weiss F (2012). (-)-2-oxa-4-aminobicylco[3.1.0]hexane-4,6dicarboxylic acid (LY379268) and 3-[(2-methyl-1,3-thiazol-4-yl)ethynyl]piperidine 
(MTEP) similarly attenuate stress-induced reinstatement of cocaine seeking. Addict Biol 17: 557-564.

McFarland K, Davidge SB, Lapish CC, Kalivas PW (2004). Limbic and motor circuitry underlying footshock-induced reinstatement of cocaine-seeking behavior. J Neurosci 24: 1551-1560.

McGaugh JL (2004). The amygdala modulates the consolidation of memories of emotionally arousing experiences. Annu Rev Neurosci 27: 1-28.

McKee SA, Potenza MN, Kober H, Sofuoglu M, Arnsten AF, Picciotto MR et al (2014). A translational investigation targeting stress-reactivity and prefrontal cognitive control with guanfacine for smoking cessation. J Psychopharmacol (in press).

McLaughlin JP, Marton-Popovici M, Chavkin C (2003). Kappa opioid receptor antagonism and prodynorphin gene disruption block stress-induced behavioral responses. J Neurosci 23: 5674-5683.

McReynolds JR, Vranjkovic O, Thao M, Baker DA, Makky K, Lim Y et al (2014). Beta-2 adrenergic receptors mediate stress-evoked reinstatement of cocaineinduced conditioned place preference and increases in CRF mRNA in the bed nucleus of the stria terminalis in mice. Psychopharmacology (Berl) 231 3953-3963.

Meil WM, See RE (1996). Conditioned cued recovery of responding following prolonged withdrawal from self-administered cocaine in rats: an animal model of relapse. Behav Pharmacol 7: 754-763.

Mongeau R, Blier P, de Montigny C (1997). The serotonergic and noradrenergic systems of the hippocampus: their interactions and the effects of antidepressant treatments. Brain Res Rev 23: 145-195.

Moore RY, Bloom FE (1979). Central catecholaimine neuron systems: anatomy and physiology of the norepinephrine and epinephrine systems. Annu Rev Neurosci 2: 113-168.

Moran-Santa Maria MM, Baker NL, Ramakrishnan V, Brady KT, McRae-Clark A (2015a). Impact of acute guanfacine administration on stress and cue reactivity in cocaine-dependent individuals. Am J Drug Alcohol Abuse 41: 146-152.

Moran-Santa Maria MM, McRae-Clark A, Baker NL, Ramakrishnan V, Brady KT (2015b). Yohimbine administration and cue-reactivity in cocaine-dependent individuals. Psychopharmacology 231: 4157-4165.

Morley JE, Levine AS (1982). Corticotrophin releasing factor, grooming and ingestive behavior. Life Sci 31: 1459-1464.

Nair SG, Adams-Deutsch T, Epstein DH, Shaham Y (2009). The neuropharmacology of relapse to food seeking: methodology, main findings, and comparison with relapse to drug seeking. Prog Neurobiol 89: 18-45.

Nair SG, Golden SA, Shaham Y (2008). Differential effects of the hypocretin 1 receptor antagonist SB 334867 on high-fat food self-administration and reinstatement of food seeking in rats. Br J Pharmacol 154: 406-416.

Nair SG, Navarre BM, Cifani C, Pickens CL, Bossert JM, Shaham Y (2011). Role of dorsal medial prefrontal cortex dopamine D1-family receptors in relapse to highfat food seeking induced by the anxiogenic drug yohimbine. Neuropsychopharmacology 36: 497-510.

Nawata Y, Kitaichi K, Yamamoto T (2012). Increases of CRF in the amygdala are responsible for reinstatement of methamphetamine-seeking behavior induced by footshock. Pharmacol Biochem Behav 101: 297-302.

Nielsen CK, Simms JA, Bito-Onon JJ, Li R, Ananthan S, Bartlett SE (2012). The delta opioid receptor antagonist, SoRI-9409, decreases yohimbine stress-induced reinstatement of ethanol-seeking. Addict Biol 17: 224-234.

O'Brien CP (2005). Anticraving medications for relapse prevention: a possible new class of psychoactive medications. Am J Psychiatry 162: 1423-1431.

Omelchenko N, Sesack SR (2007). Glutamate synaptic inputs to ventral tegmental area neurons in the rat derive primarily from subcortical sources. Neuroscience 146: 1259-1274.

Piazza PV, Le Moal M (1998). The role of stress in drug self-administration. Trends Pharmacol Sci 19: 67-74.

Pickens CL, Cifani C, Navarre BM, Eichenbaum H, Theberge FR, Baumann MH et al (2012). Effect of fenfluramine on reinstatement of food seeking in female and male rats: implications for the predictive validity of the reinstatement model. Psychopharmacology (Berl) 221: 341-353.

Pierce RC, Kumaresan V (2006). The mesolimbic dopamine system: the final common pathway for the reinforcing effect of drugs of abuse? Neurosci Biobehav Rev 30: 215-238.

Plaza-Zabala A, Martin-Garcia E, de Lecea L, Maldonado R, Berrendero F (2010). Hypocretins regulate the anxiogenic-like effects of nicotine and induce reinstatement of nicotine-seeking behavior. J Neurosci 30: 2300-2310.

Polter AM, Bishop RA, Briand LA, Graziane NM, Pierce RC, Kauer JA (2014). Poststress block of kappa opioid receptors rescues long-term potentiation of inhibitory synapses and prevents reinstatement of cocaine seeking. Biol Psychiatry 76: 785-793.

Price ML, Curtis AL, Kirby LG, Valentino RJ, Lucki I (1998). Effects of corticotropinreleasing factor on brain serotonergic activity. Neuropsychopharmacology 18: 492-502.
Redila VA, Chavkin C (2008). Stress-induced reinstatement of cocaine seeking is mediated by the kappa opioid system. Psychopharmacology 200: 59-70.

Redmond DEJ, Huang YH (1979). Locus coeruleus and anxiety. Life Sci 25 : 2149-2162.

Regier PS, Claxton AB, Zlebnik NE, Carroll ME (2014). Cocaine-, caffeine-, and stress-evoked cocaine reinstatement in high vs. low impulsive rats: treatment with allopregnanolone. Drug Alcohol Depend 143: 58-64.

Ribeiro Do Couto B, Aguilar MA, Manzanedo C, Rodriguez-Arias M, Armario A, Minarro $J$ (2006). Social stress is as effective as physical stress in reinstating morphine-induced place preference in mice. Psychopharmacology 185 459-470.

Richards JK, Simms JA, Steensland P, Taha SA, Borgland SL, Bonci A et al (2008). Inhibition of orexin-1/hypocretin-1 receptors inhibits yohimbine-induced reinstatement of ethanol and sucrose seeking in Long-Evans rats. Psychopharmacology (Berl) 199: 109-117.

Rodaros D, Caruana DA, Amir S, Stewart J (2007). Corticotropin-releasing factor projections from limbic forebrain and paraventricular nucleus of the hypothalamus to the region of the ventral tegmental area. Neuroscience 150: 8-13.

Rotllant D, Ons S, Carrasco J, Armario A (2002). Evidence that metyrapone can act as a stressor: effect on pituitary-adrenal hormones, plasma glucose and brain c-fos induction. Eur J Neurosci 16: 693-700.

Sakanaka M, Shibasaki T, Lederis K (1986). Distribution and efferent projections of corticotropin-releasing factor-like immunoreactivity in the rat amygdaloid complex. Brain Res 382: 213-238.

Sanchez CJ, Bailie TM, Wu WR, Li N, Sorg BA (2003). Manipulation of dopamine d1like receptor activation in the rat medial prefrontal cortex alters stress- and cocaine-induced reinstatement of conditioned place preference behavior. Neuroscience 119: 497-505.

Sanchez CJ, Sorg BA (2001). Conditioned fear stimuli reinstate cocaine-induced conditioned place preference. Brain Res 908: 86-92.

Sarnyai Z, Shaham Y, Heinrichs SC (2001). The role of corticotropin-releasing factor in drug addiction. Pharmacol Rev 53: 209-244.

Sawchenko PE, Li HY, Ericsson A (2000). Circuits and mechanisms governing hypothalamic responses to stress: a tale of two paradigms. Prog Brain Res 122 $61-78$

Schank JR, Goldstein AL, Rowe KE, King CE, Marusich JA, Wiley JL et al (2012). The kappa opioid receptor antagonist JDTic attenuates alcohol seeking and withdrawal anxiety. Addict Biol 17: 634-647.

Schank JR, King CE, Sun H, Cheng K, Rice KC, Heilig M et al (2014). The role of the neurokinin-1 receptor in stress-induced reinstatement of alcohol and cocaine seeking. Neuropsychopharmacology 39: 1093-1101.

Schank JR, Pickens CL, Rowe KE, Cheng K, Thorsell A, Rice KC et al (2011). Stress-induced reinstatement of alcohol-seeking in rats is selectively suppressed by the neurokinin 1 (NK1) antagonist L822429. Psychopharmacology (Berl) 218 $111-119$

Schmoutz CD, Zhang Y, Runyon SP, Goeders NE (2012). Antagonism of the neuropeptide S receptor with RTI-118 decreases cocaine self-administration and cocaine-seeking behavior in rats. Pharmacol Biochem Behav 103: 332-337.

Schroeder JP, Epps SA, Grice TW, Weinshenker D (2013). The selective dopamine beta-hydroxylase inhibitor nepicastat attenuates multiple aspects of cocaineseeking behavior. Neuropsychopharmacology 38: 1032-1038.

Schulz DW, Mansbach RS, Sprouse J, Braselton JP, Collins J, Corman M et al (1996). CP154,526: a potent and selective non-peptide antagonist of corticotropin releasing factor receptors. Proc Natl Acad Sci USA 93: 10477-10482.

Seamans JK, Durstewitz D, Christie BR, Stevens CF, Sejnowski TJ (2001). Dopamine D1/D5 receptor modulation of excitatory synaptic inputs to layer $\mathrm{V}$ prefrontal cortex neurons. Proc Natl Acad Sci USA 98: 301-306.

Sedki F, Eigenmann K, Gelinas J, Schouela N, Courchesne S, Shalev U (2015). A role for kappa-, but not mu-opioid, receptor activation in acute food deprivationinduced reinstatement of heroin seeking in rats. Addict Biol 20: 423-432.

See RE (2005). Neural substrates of cocaine-cue associations that trigger relapse. Eur J Pharmacol 526: 140-146.

See RE, Waters RP (2010). Pharmacologically-induced stress: a cross-species probe for translational research in drug addiction and relapse. Am J Trans/ Res 3 : 81-89.

Sekino A, Ohata H, Mano-Otagiri A, Arai K, Shibasaki T (2004). Both corticotropinreleasing factor receptor type 1 and type 2 are involved in stress-induced inhibition of food intake in rats. Psychopharmacology 176: 30-38.

Self DW (2004). Regulation of drug-taking and -seeking behaviors by neuroadaptations in the mesolimbic dopamine system. Neuropharmacology 47 242-255.

Seligman MEP, Maier SF (1967). Failure to escape traumatic shock. J Exp Psychol 74: 1-9.

Selye H (1936). A syndrome produced by diverse nocuous agents. Nature 138: 32-36. 
Sesack SR, Deutch AY, Roth RH, Bunney BS (1989). Topographical organization of the efferent projections of the medial prefrontal cortex in the rat: an anterograde tract-tracing study with Phaseolus vulgaris leucoagglutinin. J Comp Neurol 290: $213-242$.

Setlow B, Holland PC, Gallagher M (2002). Disconnection of the basolateral amygdala complex and nucleus accumbens impairs appetitive pavlovian secondorder conditioned responses. Behav Neurosci 116: 267-275.

Shaham Y, Erb S, Leung S, Buczek Y, Stewart J (1998). CP-154,526, a selective, non-peptide antagonist of the corticotropin-releasing factor1 receptor attenuates stress-induced relapse to drug seeking in cocaine- and heroin-trained rats. Psychopharmacology 137: 184-190.

Shaham Y, Erb S, Stewart J (2000a). Stress-induced relapse to heroin and cocaine seeking in rats: a review. Brain Res Brain Res Rev 33: 13-33.

Shaham Y, Funk D, Erb S, Brown TJ, Walker CD, Stewart J (1997). Corticotropinreleasing factor, but not corticosterone, is involved in stress-induced relapse to heroin-seeking in rats. J Neurosci 17: 2605-2614.

Shaham Y, Highfield D, Delfs J, Leung S, Stewart J (2000b). Clonidine blocks stressinduced reinstatement of heroin seeking in rats: an effect independent of locus coeruleus noradrenergic neurons. Eur J Neurosci 12: 292-302.

Shaham Y, Shalev U, Lu L, De Wit H, Stewart J (2003). The reinstatement model of drug relapse: history, methodology and major findings. Psychopharmacology 168: 3-20.

Shaham Y, Stewart J (1995). Stress reinstates heroin-seeking in drug-free animals: an effect mimicking heroin, not withdrawal. Psychopharmacology 119: 334-341.

Shaham Y, Stewart J (1996). Effects of opioid and dopamine receptor antagonists on relapse induced by stress and re-exposure to heroin in rats. Psychopharmacology 125: 385-391.

Shalev U, Erb S, Shaham Y (2010). Role of CRF and other neuropeptides in stressinduced reinstatement of drug seeking. Brain Res 1314: 15-28.

Shalev U, Finnie PS, Quinn T, Tobin S, Wahi P (2006). A role for corticotropinreleasing factor, but not corticosterone, in acute food-deprivation-induced reinstatement of heroin seeking in rats. Psychopharmacology (Berl) 187: 376-384.

Shalev U, Grimm JW, Shaham Y (2002). Neurobiology of relapse to heroin and cocaine seeking: a review. Pharmacol Rev 54: 1-42.

Shalev U, Highfield D, Yap J, Shaham Y (2000). Stress and relapse to drug seeking in rats: studies on the generality of the effect. Psychopharmacology 150: 337-346.

Shalev U, Marinelli M, Baumann MH, Piazza PV, Shaham Y (2003). The role of corticosterone in food deprivation-induced reinstatement of cocaine seeking in the rat. Psychopharmacology 168: 170-176.

Shalev U, Morales M, Hope B, Yap J, Shaham Y (2001). Time-dependent changes in extinction behavior and stress-induced reinstatement of drug seeking following withdrawal from heroin in rats. Psychopharmacology 156: 98-107.

Shelton KL, Beardsley PM (2005). Interaction of extinguished cocaine-conditioned stimuli and footshock on reinstatement in rats. Int J Comp Psychol 18: 154-166.

Shepard JD, Bossert JM, Liu SY, Shaham Y (2004). The anxiogenic drug yohimbine reinstates methamphetamine seeking in a rat model of drug relapse. Biol Psychiatry 55: 1082-1089.

Shiffman S, Wills TA (1985). Coping and Substance Abuse. Academic Press: Orlando.

Sidhpura N, Weiss F, Martin-Fardon R (2010). Effects of the mGlu2/3 agonist LY379268 and the mGlu5 antagonist MTEP on ethanol seeking and reinforcement are differentially altered in rats with a history of ethanol dependence. Biol Psychiatry 67: 804-811.

Silberman Y, Winder DG (2013). Emerging role for corticotropin releasing factor signaling in the bed nucleus of the stria terminalis at the intersection of stress and reward. Front Psychiatry 4: 42

Simms JA, Haass-Koffler CL, Bito-Onon J, Li R, Bartlett SE (2012). Mifepristone in the central nucleus of the amygdala reduces yohimbine stress-induced reinstatement of ethanol-seeking. Neuropsychopharmacology 37: 906-918.

Sinha R (2001). How does stress increase risk of drug abuse and relapse. Psychopharmacology 158: 343-359.

Sinha R (2009). Modeling stress and drug craving in the laboratory: implications for addiction treatment development. Addict Biol 14: 84-98.

Sinha R, Catapano D, O'Malley S (1999). Stress-induced craving and stress response in cocaine dependent individuals. Psychopharmacology 142: 343-351.

Sinha R, Fox HC, Hong KI, Hansen J, Tuit K, Kreek MJ (2011a). Effects of adrenal sensitivity, stress- and cue-induced craving, and anxiety on subsequent alcohol relapse and treatment outcomes. Arch Gen Psychiatry 68: 942-952.

Sinha R, Fuse T, Aubin LR, O'Malley SS (2000). Psychological stress, drug -related cues and cocaine craving. Psychopharnacology 152: 140-148.
Sinha R, Garcia M, Paliwal P, Kreek MJ, Rounsaville BJ (2006). Stress-induced cocaine craving and hypothalamic-pituitary-adrenal responses are predictive of cocaine relapse outcomes. Arch Gen Psychiatry 63: 324-331.

Sinha R, Kimmerling A, Doebrick C, Kosten TR (2007). Effects of lofexidine on stress-induced and cue-induced opioid craving and opioid abstinence rates: preliminary findings. Psychopharmacology 190: 569-574.

Sinha R, Shaham Y, Heilig M (2011b). Translational and reverse translational research on the role of stress in drug craving and relapse. Psychopharmacology (Berl) 218: 69-82.

Smith RJ, Aston-Jones G (2011). alpha(2) Adrenergic and imidazoline receptor agonists prevent cue-induced cocaine seeking. Biol Psychiatry 70: 712-719.

Staub DR, Lunden JW, Cathel AM, Dolben EL, Kirby LG (2012). Morphine history sensitizes postsynaptic GABA receptors on dorsal raphe serotonin neurons in a stress-induced relapse model in rats. Psychoneuroendocrinology 37: 859-870.

Stefanik MT, Kupchik YM, Brown RM, Kalivas PW (2013). Optogenetic evidence that pallidal projections, not nigral projections, from the nucleus accumbens core are necessary for reinstating cocaine seeking. J Neurosci 33: 13654-13662.

Stewart J, de Wit H (1987). Reinstatement of drug-taking behavior as a method of assessing incentive motivational properties of drugsin:Bozarth MA (ed) Methods of Assessing the Reinforcing Properties of Abused Drugs. Springer-Verlag: New York. pp 211-227.

Stone EA (1983). Adaptation to stress and brain noradrenergic receptors. Neurosci Biobehav Rev 7: 503-509.

Stopponi S, de Guglielmo G, Somaini L, Cippitelli A, Cannella N, Kallupi M et al (2013). Activation of PPARgamma by pioglitazone potentiates the effects of naltrexone on alcohol drinking and relapse in msP rats. Alcohol Clin Exp Res 37: 1351-1360.

Stopponi S, Somaini L, Cippitelli A, Cannella N, Braconi S, Kallupi M et al (2011). Activation of nuclear PPARgamma receptors by the antidiabetic agent pioglitazone suppresses alcohol drinking and relapse to alcohol seeking. Biol Psychiatry 69: 642-649.

Stopponi S, Somaini L, Cippitelli A, de Guglielmo G, Kallupi M, Cannella N et al (2012). Pregabalin reduces alcohol drinking and relapse to alcohol seeking in the rat. Psychopharmacology (Berl) 220: 87-96.

Takahata R, Moghaddam B (1998). Glutamatergic regulation of basal and stimulusactivated dopamine release in the prefrontal cortex. I Neurochem 71: 1443-1449.

Thierry AM, Tassin JP, Blanc G, Glowinski J (1976). Selective activation of mesocortical DA system by stress. Nature 263: 242-244.

Tobin S, Newman AH, Quinn T, Shalev U (2009). A role for dopamine D1-like receptors in acute food deprivation-induced reinstatement of heroin seeking in rats. Int J Neuropsychopharmacol 12: 217-226.

Tobin S, Sedki F, Abbas Z, Shalev U (2013). Antagonism of the dopamine D1-like receptor in mesocorticolimbic nuclei attenuates acute food deprivation-induced reinstatement of heroin seeking in rats. Eur J Neurosci 37: 972-981.

Twining RC, Wheeler DS, Ebben AL, Jacobsen AJ, Robble MA, Mantsch JR et al (2015). Aversive stimuli Drive drug seeking in a state of low dopamine tone. Biol Psychiatry 77: 895-902.

Umhau JC, Schwandt ML, Usala J, Geyer C, Singley E, George TD et al (2011). Pharmacologically induced alcohol craving in treatment seeking alcoholics correlates with alcoholism severity, but is insensitive to acamprosate. Neuropsychopharmacology 60: 303-311.

Ungless MA, Singh V, Crowder TL, Yaka R, Ron D, Bonci A (2003). Corticotropinreleasing factor requires $\mathrm{CRF}$ binding protein to potentiate NMDA receptors via CRF receptor 2 in dopamine neurons. Neuron 39: 401-407.

Valdez GR, Platt DM, Rowlett JK, Ruedi-Bettschen D, Spealman RD (2007). Kappa agonist-induced reinstatement of cocaine seeking in squirrel monkeys: a role for opioid and stress-related mechanisms. J Pharmacol Exp Ther 323: 525-533.

Van't Veer A, Carlezon WA Jr. (2013). Role of kappa-opioid receptors in stress and anxiety-related behavior. Psychopharmacology (Berl) 229: 435-452.

Van Pett K, Viau V, Bittencourt JC, Chan RK, Li HY, Arias C et al (2000). Distribution of mRNAs encoding CRF receptors in brain and pituitary of rat and mouse. J Comp Neurol 428: 191-212.

Vaughn LK, Mantsch JR, Vranjkovic O, Stroh G, Lacourt M, Kreutter M et al (2012). Cannabinoid receptor involvement in stress-induced cocaine reinstatement: potential interaction with noradrenergic pathways. Neuroscience 204: 117-124.

Vertes RP (1991). A PHA-L analysis of ascending projections of the dorsal raphe nucleus in the rat. J Comp Neuro/ 313: 643-668.

Vertes RP, Fortin WJ, Crane AM (1999). Projections of the median raphe nucleus in the rat. J Comp Neurol 407: 555-582.

Vranjkovic O, Gasser PJ, Gerndt CH, Baker DA, Mantsch JR (2014). Stress-induced cocaine seeking requires a beta-2 adrenergic receptor-regulated pathway from the ventral bed nucleus of the stria terminalis that regulates CRF actions in the ventral tegmental area. J Neurosci 34: 12504-12514. 
Vranjkovic O, Hang S, Baker DA, Mantsch JR (2012). beta-adrenergic receptor mediation of stress-induced reinstatement of extinguished cocaine-induced conditioned place preference in mice: roles for beta1 and beta2 adrenergic receptors. J Pharmacol Exp Ther 342: 541-551.

Wang B, Luo F, Zhang WT, Han JS (2000). Stress or drug priming induces reinstatement of extinguished conditioned place preference. Neuroreport 11: 2781-2784.

Wang B, Shaham Y, Zitzman D, Azari S, Wise RA, You ZB (2005). Cocaine experience establishes control of midbrain glutamate and dopamine by corticotropin-releasing factor: a role in stress-induced relapse to drug seeking. J Neurosci 25: 5389-5396.

Wang B, You ZB, Rice KC, Wise RA (2007). Stress-induced relapse to cocaine seeking: roles for the $\mathrm{CRF}(2)$ receptor and CRF-binding protein in the ventral tegmental area of the rat. Psychopharmacology 193: 283-294.

Wang B, You ZB, Wise RA (2009). Reinstatement of cocaine seeking by hypocretin (orexin) in the ventral tegmental area: independence from the local corticotropinreleasing factor network. Biol Psychiatry 65: 857-862.

Wang B, You ZB, Wise RA (2012). Heroin self-administration experience establishes control of ventral tegmental glutamate release by stress and environmental stimuli. Neuropsychopharmacology 37: 2863-2869.

Wang J, Fang Q, Liu Z, Lu L (2006). Region-specific effects of brain corticotropinreleasing factor receptor type 1 blockade on footshock-stress- or drug-priminginduced reinstatement of morphine conditioned place preference in rats. Psychopharmacology 185: 19-28.

Wang X, Cen X, Lu L (2001). Noradrenaline in the bed nucleus of the stria terminalis is critical for stress-induced reactivation of morphine-conditioned place preference in rats. Eur J Pharmacol 432: 153-161.

Waters RP, See RE (2011). Chronic cocaine self-administration attenuates the anxiogenic-like and stress potentiating effects of the benzodiazepine inverse agonist, FG 7142. Pharmacol Biochem Behav 99: 408-413.

Weiss F (2005). Neurobiology of craving, conditioned reward and relapse. Curr Opin Pharmacol 5: 9-19.

Weiss RD (2004). Adherence to pharmacotherapy in patients with alcohol and opioid dependence. Addiction 99: 1382-1392.
Westerink BH, Kwint HF, deVries JB (1996). The pharmacology of mesolimbic dopamine neurons: a dual-probe microdialysis study in the ventral tegmental area and nucleus accumbens of the rat brain. I Neurosci 16: 2605-2611.

White FJ, Hu XT, Zhang XF, Wolf ME (1995). Repeated administration of cocaine or amphetamine alters neuronal responses to glutamate in the mesoaccumbens dopamine system. J Pharmacol Exp Ther 273: 445-454.

Xi ZX, Gilbert J, Campos AC, Kline N, Ashby CR Jr., Hagan JJ et al (2004). Blockade of mesolimbic dopamine D3 receptors inhibits stress-induced reinstatement of cocaine-seeking in rats. Psychopharmacology (Berl) 176: 57-65.

Yamada H, Bruijnzeel AW (2011). Stimulation of alpha2-adrenergic receptors in the central nucleus of the amygdala attenuates stress-induced reinstatement of nicotine seeking in rats. Neuropharmacology 60: 303-311.

Zahm DS, Williams EA, Latimer MP, Winn P (2001). Ventral mesopontine projections of the caudomedial shell of the nucleus accumbens and extended amygdala in the rat: double dissociation by organization and development. J Comp Neurol 436: 111-125.

Zhao Y, Dayas CV, Aujla H, Baptista MA, Martin-Fardon R, Weiss F (2006). Activation of group II metabotropic glutamate receptors attenuates both stress and cue-induced ethanol-seeking and modulates c-fos expression in the hippocampus and amygdala. J Neurosci 26: 9967-9974.

Zhou L, Ghee SM, Chan C, Lin L, Cameron MD, Kenny PJ et al (2012). Orexin-1 receptor mediation of cocaine seeking in male and female rats. J Pharmacol Exp Ther 340: 801-809.

Zislis G, Desai TV, Prado M, Shah HP, Bruijnzeel AW (2007). Effects of the CRF receptor antagonist D-Phe $\mathrm{CRF}(12-41)$ and the alpha2-adrenergic receptor agonist clonidine on stress-induced reinstatement of nicotine-seeking behavior in rats. Neuropharmacology 53: 958-966.

Zorrilla EP, Heilig M, de Wit H, Shaham Y (2013a). Behavioral, biological, and chemical perspectives on targeting $\mathrm{CRF}(1)$ receptor antagonists to treat alcoholism. Drug Alcohol Depend 128: 175-186.

Zorrilla EP, Roberts AJ, Rivier JE, Koob GF (2013b). Anxiolytic-like effects of antisauvagine-30 in mice are not mediated by CRF2 receptors. PLoS One 8 e63942. 